\title{
PLASMA NUTFAH IKAN HIAS SUMATERA
}

\author{
Sudarto \\ Balai Riset Budidaya Ikan Hias \\ Jl. Perikanan No. 13 Pancoran Mas, Depok \\ E-mail: bukembar@yahoo.com
}

\begin{abstract}
ABSTRAK
Data yang dikemukakan atau disampaikan oleh para ekportir ikan hias mempunyai kecenderungan adanya eksploitasi ikan hias air tawar dari alam. Banyak jenis yang diekspor umumnya berasal dari Indonesia bagian Barat khususnya dari Sumatera dan Kalimantan. Data ini dapat dikumpulkan melalui kompilasi dari para stakeholder ikan hias dan penelusuran ke sentra penangkapan ikan hias melalui survai lokasi khususnya ikan hias air tawar Sumatera. Lebih dari 100 spesies, termasuk ke dalam 31 famili telah dikompilasi dari lokasi-lokasi sentra ikan hias. Data ini khususnya merupakan gambaran jenis plasma nutfah dan potensi ikan hias asal Sumatera yang dapat dipakai untuk pengembangan di masa mendatang.
\end{abstract}

\section{KATAKUNCl: ikan hias, stakeholder, plasma nutfah}

\section{PENDAHULUAN}

Diketahui bahwa ikan hias di pasar internasional yang berasal dari Asia merupakan hasil ekspor negara Singapura, padahal ikan ikan tersebut didatangkan oleh mereka dari Indonesia, sehingga negara kita seolah-olah merupakan penyumbang kecil dalam bisnis ikan hias dunia. Tidak tersedianya data baik jenis maupun potensi ikan hias asli Indonesia sehingga sulit untuk pengambil kebijakan untuk melakukan penataan atau pengaturan. Banyak publikasi tentang ikan hias Indonesia tetapi tidak secara spesifik menyebutkan ikan Indonesia, seperti rainbow asal Papua. Disamping itupun tidak ada statistik yang menggambarkan potensi ekspor ikan hias Indonesia yang dapat dipakai sebagai acuan. Data yang ada merupakan data acuan dari BPEN yang merupakan kompilasi kegiatan ekspor ikan hias dan banyak dari data itu hanya merupakan gabungan beberapa spesies. Mungkin saja beberapa spesies digabung ke dalam 1 grup, misalnya golongan ikan seluang (Rasbora spp) masuk ke dalam grup Cyprinids, padahal golongan Cyprinidae terdiri lebih dari 80 spesies. Belum lagi jenis ikan lele-lelean yang dimasukkan ke dalam grup catfishes. Hingga saat ini sulit mendapatkan data yang akurat mengenai jenis atau spesies sebagai plasma nutfah yang dieksploitasi dari alam untuk dijual ke laur negeri, sehingga tidak diketahui berapa potensinya di alam. Tujuan inventarisasi ini adalah mendapatkan data yang akurat tentang keberadaan plasma nutfah ikan hias asli Sumatera, potensi dan aspek-aspek biologinya.

\section{BAHAN DAN METODE}

Pelaksanaan kegiatan dilakukan dengan melakukan survai ke daerah sumber ikan hias di Sumatera Jambi, Sumatera Selatan, Riau) dengan melakukan koleksi dari daerah yang dikunjungi. Sampel bisa juga didapat dari pasar ikan hias atau pengumpul, juga dilakukan dari nelayan langsung.

Ikan yang terkumpul pertama kali dilakukan dokumentasi dengan kamera digital dalam keadaan hidup segar, atau mati segar agar warna belum mengalami perubahan. Ikan hidup ditransportasi ke Balai Riset Budidaya Ikan Hias Depok untuk domestikasi. Sampel yang mati diawetkan dengan alkohol absolute untuk diidentifikasi berdasarkan buku kunci identifikasi ikan (Saanin, 1952; Nelson, Munro dan lain-lain), dan nama lokal berdasarkan hasil wawancara dan buku nama daerah berdasarkan daerah di mana ikan didapat (Schuster \& Djajadiredja, 1952). Selain itu, kelengkapan sistematika ikan dilakukan download data melalui internet www.fishbase.com; www.zipcodezoo.com

\section{HASIL DAN BAHASAN}

Dari kompilasi yang dilakukan maka telah dikumpulkan berbagai jenis plasma nutfah ikan air tawar yang berpotensi sebagai ikan hias terbagi ke dalam beberapa famili, yaitu: Akysidae, Ambassidae, Anabantidae, Ariidae, Bagridae, Balitoridae, Chacidae, Channidae, Cobitidae, Cynoglossidae, Cyprinidae (32 sp), Dasyatidae, Datnioididae, Eleotridae, Gobiidae, Helostomatidae, Hemirhampidae, Mastacembelidae, Nandidae, Notopteridae, Osphronemidae (8 spp), Osteoglossidae, Parakysidae, Polynemidae, Schilbeidae, Siluridae (8 spp), Sisoridae, Soleidae, Syngnathidae, Tetraodontidae, dan Toxosidae. 
Beberapa spesies yang sudah dikenal dan berpotensi sebagai ikan hias diuraikan berupa sinopsis pada Lampiran.

\section{KESIMPULAN DAN SARAN}

Hasil survai mendapatkan lebih dari 100 spesies ikan hias air tawar yang terdapat di Sumatera yang terdiri atas 31 famili. Kebanyakan dari ikan-ikan ini belum dibudidayakan walaupun ada kecenderungan populasinya menurun dari waktu ke waktu di mana saat-saat tertentu sulit didapat dan untuk penyelamatannya belum ada usaha konservasi atau aturan penangkapan sehingga tidak terjadi overfishing. Oleh karena itu, disarankan adanya upaya aturan penangkapan serta data spesies yang ditangkap dan larangan-larangan guna pelestarian ikan di alam dan usaha budidaya di luar habitatnya agar tidak terjadi kepunahan.

\section{DAFTAR ACUAN}

Gustiano, R. 2003. Taxonomy and phylogeny of Pangasiidae catfishes from Asia (Ostariophysi, Siluriformes). Katholieke Universiteit Leuven Faculty of Sciences Department of Biology, section of ecology and systematics laboratory of comparative anatomy and biodiversity B-3000, Leuven, Belgium. Thesis.

Kottelat, M., Whitten; A.J., Kartikasari; S.N., \& Wirjoatmodjo, S. 1995. Freshwater Fishes of Western Indonesia and Sulawesi. Periplus Edition (HK) Ltd. And Ministry of State for Population and Environtment. Rep. of Indonesia, 293 pp.
Paysan, K. 1975. The country life guide to Aquarium Fishes. Country Life Books, 239 pp.

Pouyaud, L., Sudarto, \& Teugels, G.G. 2003. The different colour varieties of the Asian arowana Scaleropages formosus (Osteoglossidae) are distinct species: Morphologic and genetics evidences. Cybium, 27(4): 287305.

Roberts, T.R. 1989. The freshwater fishes of Western Borneo (Kalimantan Barat, Indonesia). California Academy of Sciences. San Francisco, 210 pp.

Rustami, D. \& Schuster, V. 1952. Local common names of Indonesia fishes. Jakarta, $200 \mathrm{hlm}$.

Saanin, H. 1952. Kunci identifikasi ikan. Van Hoeve, Bandung, $200 \mathrm{hlm}$.

Satyani, D., Priyadi, A., Subandiyah, S., Kadarini, T., \& Subagja, J. 2002. Peningkatan keberhasilan kematangan gonad dan ovulasi ikan balashark (Balashark macracanthus). Laporan Hasil Riset Perikanan Air Tawar tahun 2002. Balai Riset Perikanan Budidaya Air Tawar, $6 \mathrm{hlm}$.

Subandiyah, S., Komarudin, O., Yuliati, P., Subagja, J., \& Arianti, F.D. 1995. Penelitian kemampuan penampungan pada air resirkulasi ikan balashark. Prosiding Seminar Hasil Penelitian Perikanan Air tawar 1993/1994. Balai Penelitian Perikanan Air Tawar, Jakarta, hlm. 8285.

Sudarto. 2003. Systematic revision and phylogenetic relationships among populations of clariid species in southeast Asia. Thesis. University of Indonesia, Jakarta, 271 pp. 


\section{LAMPIRAN}

Famili : Anabantidae-Climbing Gouramies

Anabas testudineus

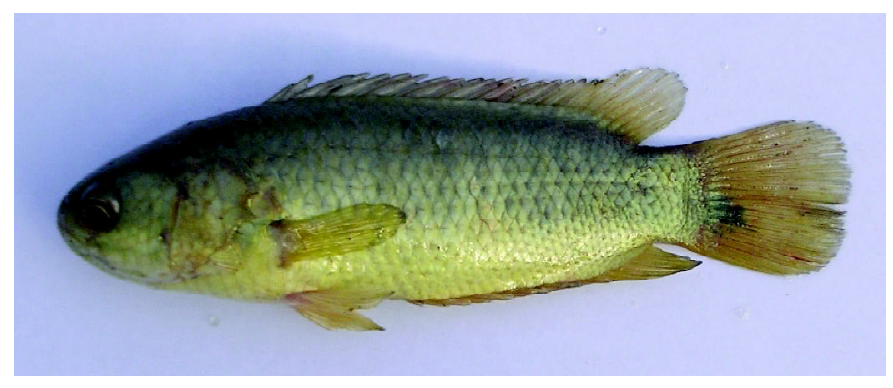

Nama Inggris/nama dagang

Nama Indonesia/nama daerah

Deskripsi morfologi

Habitat dan perkembangbiakannya

Penyebaran

Famili : Aplocheilidae- Killifishes

Aplocheilus panchax
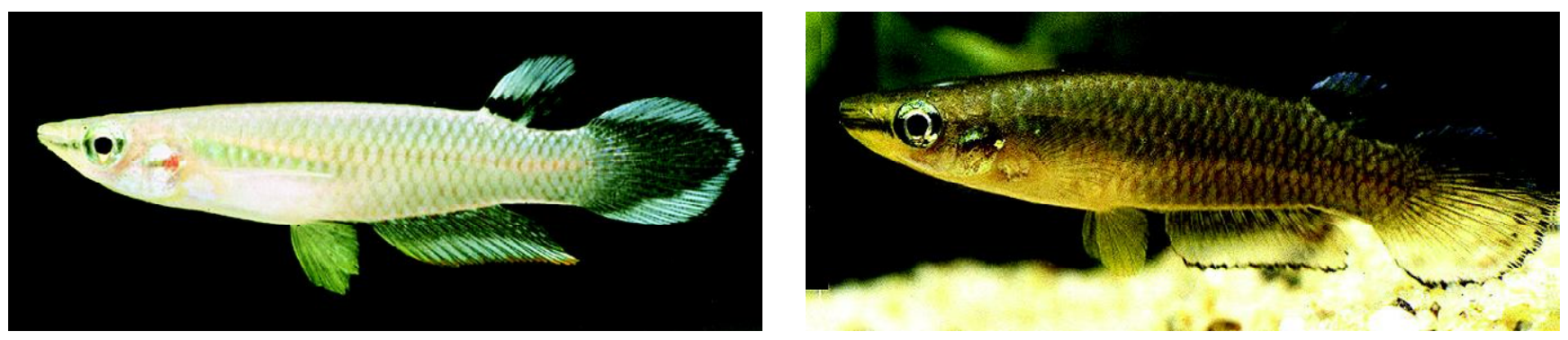

Nama Inggris/nama dagang

: Blue panchax

Nama Indonesia/nama daerah

: Ikan kepala timah

Deskripsi Morfologi

: Panjang maksimum mencapai $20 \mathrm{~cm}$

Habitat dan perkembangbiakannya
: Ikan betok, betik, betok, papuyu, betik, krucilan, puyu-puyu, pepeuyeuh, puyu, oseng, bale belang

: Panjang maksimum mencapai $25 \mathrm{~cm}$. Duri sirip punggung 16-20 buah; jari-jari lunak sirip punggung 7-10 buah; duri sirip dubur 9-11 buah; jari-jari lunak sirip dubur 8-11 buah. Tulang penutup insang (operkulum), suboperkulum, interoperkulum bergerigi; memiliki organ pernafasan tambahan (alat labirin) seperti rawa, danau, sungai. Juga hidup di daerah payau di mana dijumpai banyak tumbuhan air. Habitatnya perairan lakustrin, dengan suhu $15^{\circ} \mathrm{C}-31^{\circ} \mathrm{C}$. Pemakan segala (omnivor), predator bagi ikan-ikan yang lebih kecil

: Diketemukan di seluruh Provinsi Sumatera
: Climbing perch, walking fish, climbing bass 
Penyebaran

mangrove. Makanan utamanya insekta sehingga bisa dipakai sebagai pengendali nyamuk. Ikan ini popular sebagai ikan hias

Famili : Chacidae- Squarehead Catfishes

Chaca bankanensis

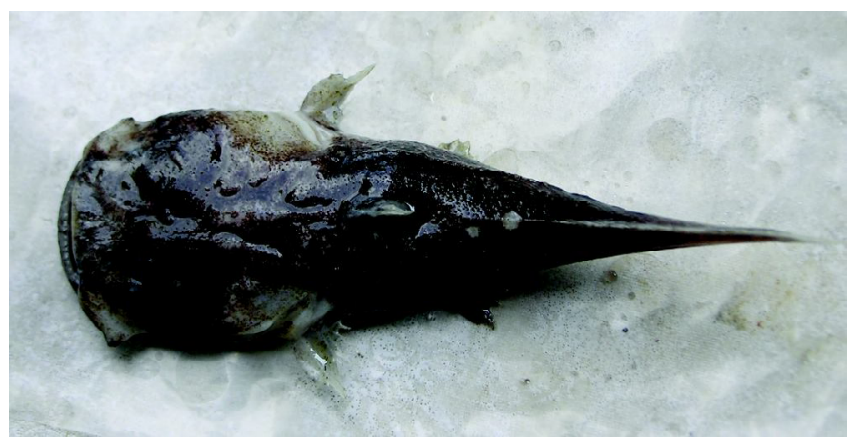

Nama Inggris/nama dagang

Nama Indonesia/nama daerah

Deskripsi morfologi

Habitat dan perkembang biakannya

Famili : Channidae- Snakeheads

Channa lucius
: Angler Catfishes, frog mouth catfish

: Tuka, anka, putting bliong, putting beliung

: Panjang maksimum mencapai $20 \mathrm{~cm}$. Ciri-cirinya seperti batu, bentuk badan menyerupai berudu dengan kepala besar bersegi, mulut besar dengan enam sungut pendek bercabang di sekelilingnya dan sirip ekor memanjang ke arah punggung. Bagian punggung berwarna coklat tua, perut putih. Duri sirip punggung dan duri sirip dada mempunyai alat pengunci. Duri sirip punggung beracun

Habitat di sungai bergambut dengan alkalinitas 4- 9 mg/L; $\mathrm{CaCO}_{3} \mathrm{pH}$ 5,3-7,2; suhu air $23,3^{\circ} \mathrm{C}-27,5^{\circ} \mathrm{C}$. M emakan segala makanan (Omnivor) 
Nama Indonesia/nama daerah

Deskripsi morfologi

Habitat dan perkembangbiakannya
: Bujuk, runtuk (Kalimantan)

: Panjang maksimum mencapai $65 \mathrm{~cm}$. Bentuk badan hampir bundar. Mempunyai alat labirin untuk menghirup udara di luar air. Terdapat satu atau dua baris gigi taring pada rahang atas dan bawah bagian depan. Sisik gurat sisi (LI) berjumlah 58-65 buah. Jari-jari sirip punggung berjumlah 38- 41 buah; jari-jari sirip dubur 27-29 buah. Anak-anaknya mempunyai tiga pita gelap dari kepala hingga dasar sirip dubur. Ikan ini mempunyai bercak-bercak besar di sepanjang kedua sisi tubuhnya dan terdapat 12-15 belang menyerong pada bagian perutnya

: Ikan ini dijumpai di sungai-sungai kecil di daerah hutan dan rawa gambut dan hidup di antara tanaman. Juga terdapat di danau, dengan $\mathrm{pH}$ antara 5,56,0 dan ikan ini bersifat predator nocturnal. Ikan ini membuat sarang seperti kebanyakan jenis gabus, di mana kedua induknya menjaga telur yang dibuahi hingga menjadi larva

\section{Channa micropeltes}

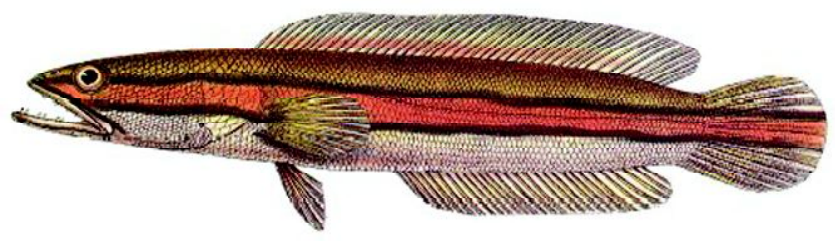

Deskripsi morfologi

Habitat dan perkembang biakannya

Status pembudidayaannya/ nilai ekonomi
: Bisa mencapai panjang lebih dari $100 \mathrm{~cm}$ dengan bobot $20 \mathrm{~kg}$. Mulut besar, gigi-gigi taring yang besar terdapat di bagian depan. Sisik di depan sirip punggung berjumlah 22 buah; ada 95-110 buah sisik di bagian longitudinal. Karena ukuran sisik yang lebih kecil dibandingkan dengan jenis gabus lainnya maka ikan ini diberi nama micropeltes (= sisik kecil). Jari-jari sirip punggung 43-46 buah; jari-jari sirip dubur 27-30 buah; jari-jari sirip dada 15 buah; jarijari sirip perut 6 buah; sirip ekornya bulat

: Hidup di danau-danau, sungai-sungai, dan waduk-waduk dan menyukai perairan yang dalam tetapi juga dijumpai di perairan yang tenang. Mencari makan pada siang hari, mangsanya antara lain ikan, kodok dan burung

: Ditangkap dari alam dan langsung dijual. Biasanya diolah untuk dijadikan ikan asin. Dijadikan ikan hias pada waktu ukuran kecil. Dibudidayakan di dalam karamba dari ukuran benih lalu dimasukkan ke dalam karamba kayu diberi pakan dengan ikan rucah yang ditangkap dari sungai, dipelihara hingga ukuran rata-rata 0,8-1,5 kg/ekor 
Channa pleurophthalma

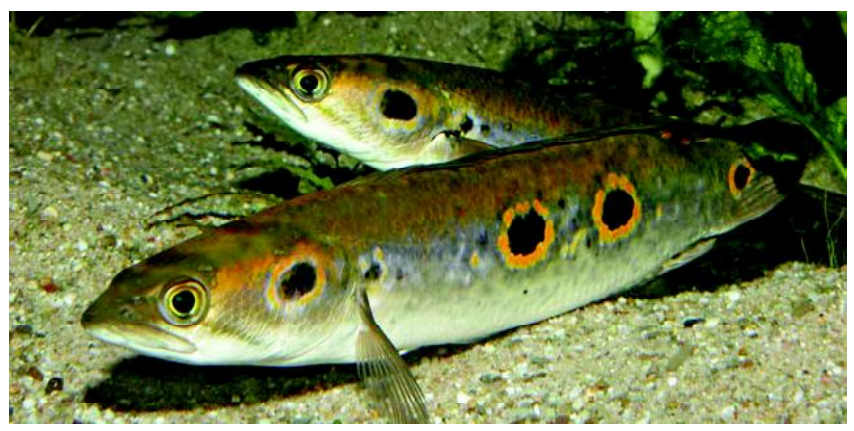

Nama Inggris/nama dagang

Nama Indonesia/nama daerah

Deskripsi morfologi

Habitat
: Snakeheads

: Serandang

: Panjang maksimum mencapai $45 \mathrm{~cm}$. Terdapat 4-5 bercak bulat hitam di bagian sisi badan dengan bulatan kuning; terdapat satu deret gigi bentuk taring pada rahang atas; satu deretan gigi-gigi kecil dan 4- 5 gigi berbentuk taring pada palatine. Anak yang belum dewasa (ikan muda) memperlihatkan sebuah pola melingkar terdiri dari 4- 6 pita hitam memanjang pada bagian tubuhnya, dan noktah hitam lembut pada kedua sisinya

: Hidup di daerah yang beroksigen rendah dengan $\mathrm{pH}$ antara 5,5-7 dan suhu air $25^{\circ} \mathrm{C}-31^{\circ} \mathrm{C}$. Bersifat karnifora, hidup pada daerah bentopelagis perairan tawar juga di perairan gambut berwarna hitam

Famili : Cobitidae- Loaches

Acantopsis choirorhynchos

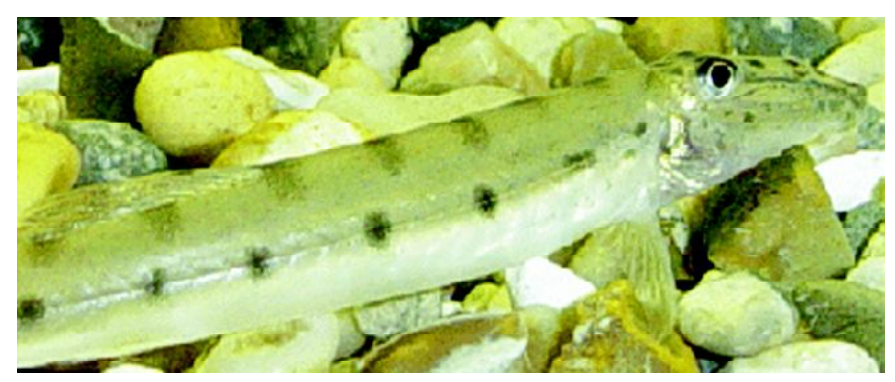

Nama Inggris/nama dagang Nama Indonesia/nama daerah Habitat
: Horseface loach

: Ikanjeler

: Hidup di air tawar di bagian demersal; dengan $\mathrm{pH}$ 6,0-6,5, yaitu di sungaisungai di mana mereka makan hewan-hewan kecil di endapan dasar 
Chromobotia macracanthus

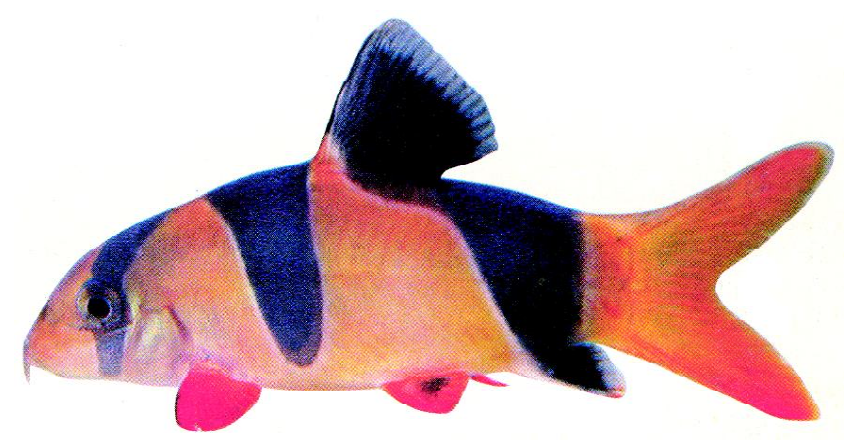

Nama Inggris/nama dagang

Nama Indonesia/nama daerah

Deskripsi morfologi

Habitat dan perkembangbiakannya

Daerah penyebaran

Status pembudidayaannya/ nilai ekonomi
: Clown Loach, Red Botia

: Botia, Bajubang, merah

: Panjang maksimum bisa mencapai $30 \mathrm{~cm}$. Badan lonjong; berwarna oranye dengan tiga pita hitam, sirip ekor bercagak dalam, ujungnya berwarna kemerahan. Sirip anus hitam dengan tulang sirip kuning, sementara sirip dada merah darah. Di ujung kepala terdapat mulut yang berkumis, sedangkan di bawah matanya terdapat semacam duri tajam yang digunakan sebagai senjata, sehingga dijuluki juga si mata duri (thorn eyes). Macracantha sendiri (nama latin dari ikan ini) berarti ikan yang memiliki duri "besar". Betina pada umumnya memiliki badan lebih ramping dibandingkan dengan jantan. Sedangkan jantan ditandai dengan sirip ekor lebih panjang dibandingkan dengan betina

: Botia ditemukan berkumpul di perairan yang tenang di gua-gua di dalam sungai (tidak berarus deras). Sifat lain yang juga menonjol dari ikan ini adalah kebiasaannya merayap di dasar air sehingga dijuluki perayap lumpur, sedangkan botia tidak senang lumpur

: Ikan botia merupakan ikan asli Sumatera dan Kalimantan

: Sudah bisa dibudidayakan di hatcheri. Di alam memakan binatang-binatang kecil di dalam endapan, tetapi di dalam domestikasi dapat diberi pakan alami berupa larva chironomus, blood worm, daging cumi-cumi, dan pelet. Merupakan ikan hias dengan harga relatif mahal

\section{Pangio kuhlii}
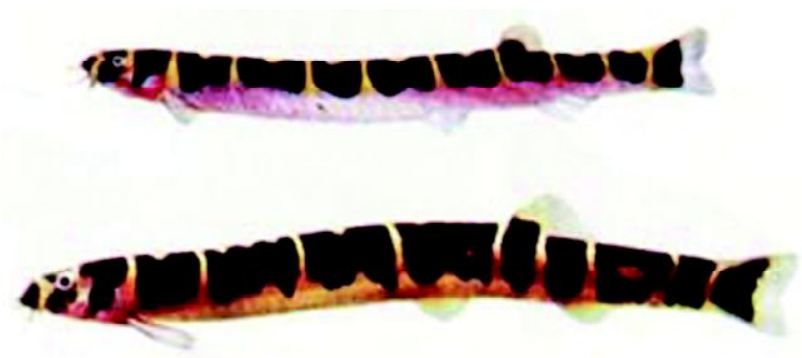

Nama Inggris/nama dagang

: Cooli loach, Coolie Loach, Giant Coolie Loach, Kuhli Loach, Leopard Loach, Slimy Loach, Slimy Myersi 
Nama Indonesia/nama daerah

Deskripsi morfologi

Habitat dan perkembangbiakannya
: Ikan sili-sili

: Panjang maksimum mencapai $12 \mathrm{~cm}$. Vertebra 47-51 buah. Pola warna terdiri dari 6-10 pita, biasanya tak beraturan, dengan noktah warna hitam segi empat menempati bagian depan dari sirip ekor; bagian bawah bibir tak ada sungut

Hidup di perairan dasar dengan $\mathrm{pH} 7$ dan temperatur $28^{\circ} \mathrm{C}$, makanannya berupa pakan hidup. Demersal, air tawar; pH 5,5-6,5. Hidup di sungai-sungai dataran tinggi hingga hutan dataran rendah, kanal, dan rawa gambut. Berkembang biak secara ovipar. Dalam perdagangan ikan hias dikenal dengan nama "Kuhli's loach"

Syncrossus hymenophysa

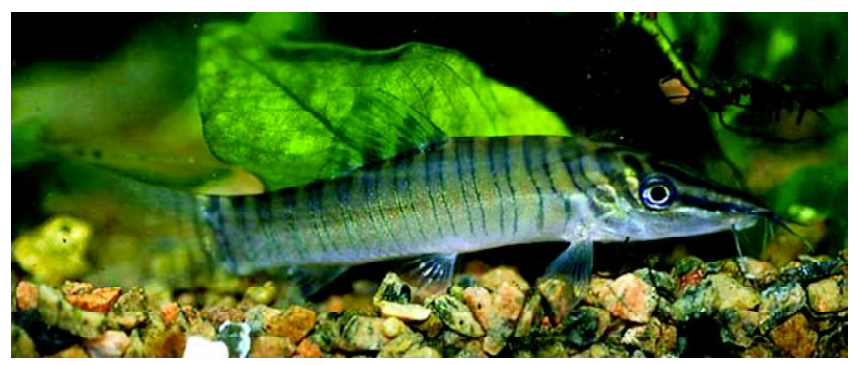

Nama Inggris/nama dagang

Nama Indonesia/nama daerah

Deskripsi morfologi

Habitat dan perkembangbiakannya
: Green Botia, tiger botia, Banded Loach, Tiger Loach, Zebra Loach

: Langli

: Panjang maksimum mencapai $21 \mathrm{~cm}$. Badan lonjong; mata tidak tertutup kulit; sirip ekor bercagak dalam berwarna kuning pucat dengan pita warna hitam yang berdiri vertikal. Memiliki 12-14 pita tegak berwarna kebirubiruan bertepi hitam; 12-13 buah jari-jari bercabang pada sirip punggung, terdapat bercak dan garis warna pada ujung sirip punggung. Badan mempunyai 13 jalur yang miring berwarna biru. M empunyai enam sungut, empat sungut moncong, dan sepasang sungut yang terletak di sudut mulut

Hidup di sungai air tenang, agak gelap dengan nilai alkalinitas antara 4-23 $\mathrm{mg} / \mathrm{L} \mathrm{CaCO}_{3}$ dan suhu air antara $22^{\circ} \mathrm{C}-30^{\circ} \mathrm{C}$, menyukai air yang agak bersifat asam, dengan pH antara 6,6-7,0. Hidup di danau-danau, sungai, dan kanalkanal yang berdasar bebatuan, Makanannya cacing, krustase, dan insekta 
Famili : Cyprinidae - minnows and carps

Balantiocheilos melanopterus

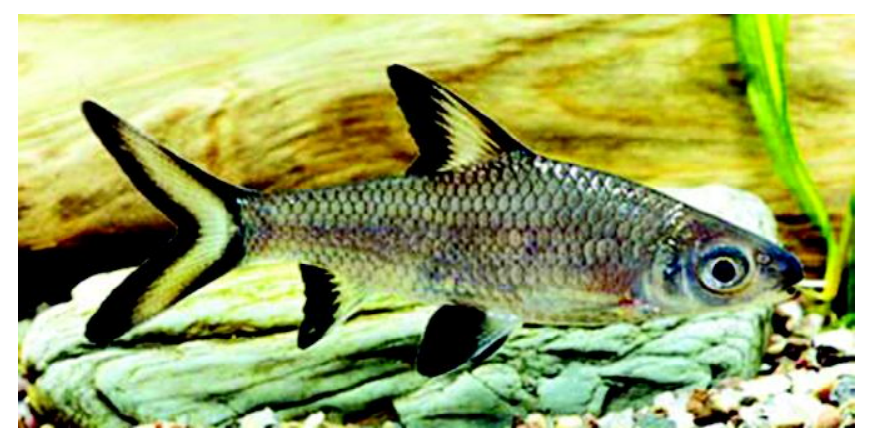

Nama Inggris/nama dagang

Nama Indonesia/nama daerah

Deskripsi morfologi

Habitat dan perkembangbiakannya

Status pembudidayaannya/ nilai ekonomi

Danio albolineatus

Nama Inggris/nama dagang Nama Indonesia/nama daerah Deskripsi morfologi

Habitat

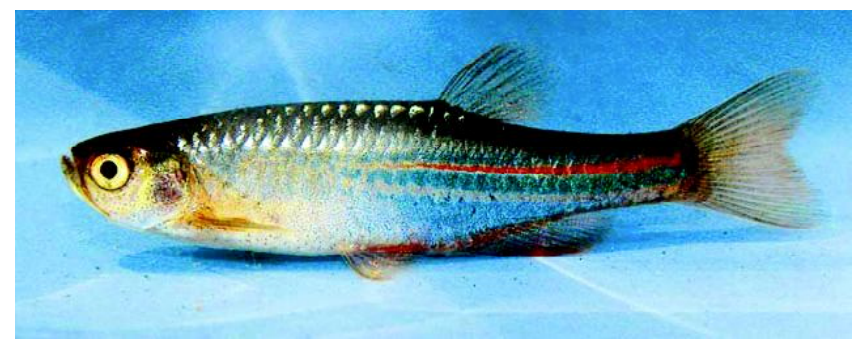

: Pearl danio, Gold Danio, Golden Danio, Spotted Danio

: Ikan seluang

: Jari-jari lunak bercabang sirip punggung 7 buah; jari-jari lunak bercabang sirip dubur 12-13 buah; gurat sisi tidak sempurna. Dua pasang sungut yang panjang

: Hidup di aliran sungai di perbukitan. Makanannya serangga kecil dan zooplankton 


\section{Epalzeorhynchos kalopterus}
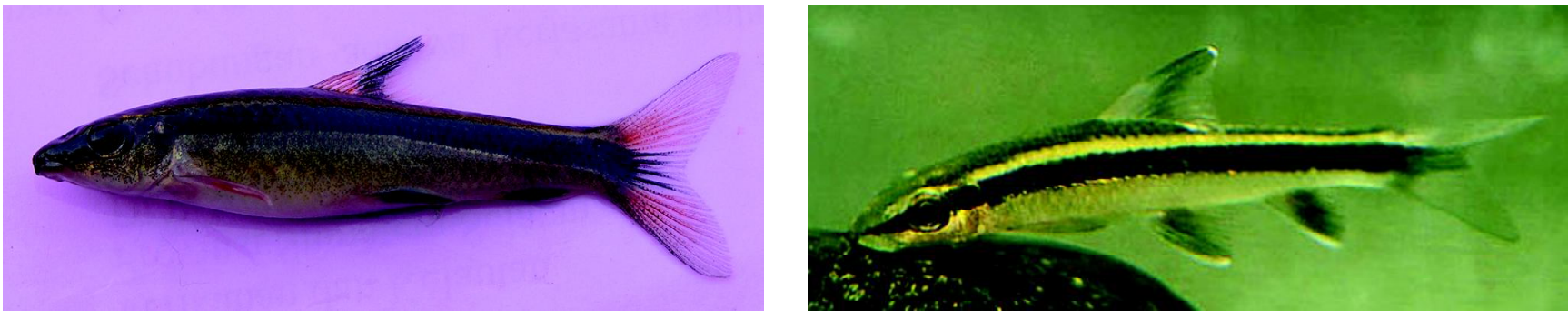

Nama Inggris/nama dagang

Nama Indonesia/nama daerah

Deskripsi morfologi

Habitat dan perkembangbiakannya

Daerah penyebaran

Labeo chrysophekadion
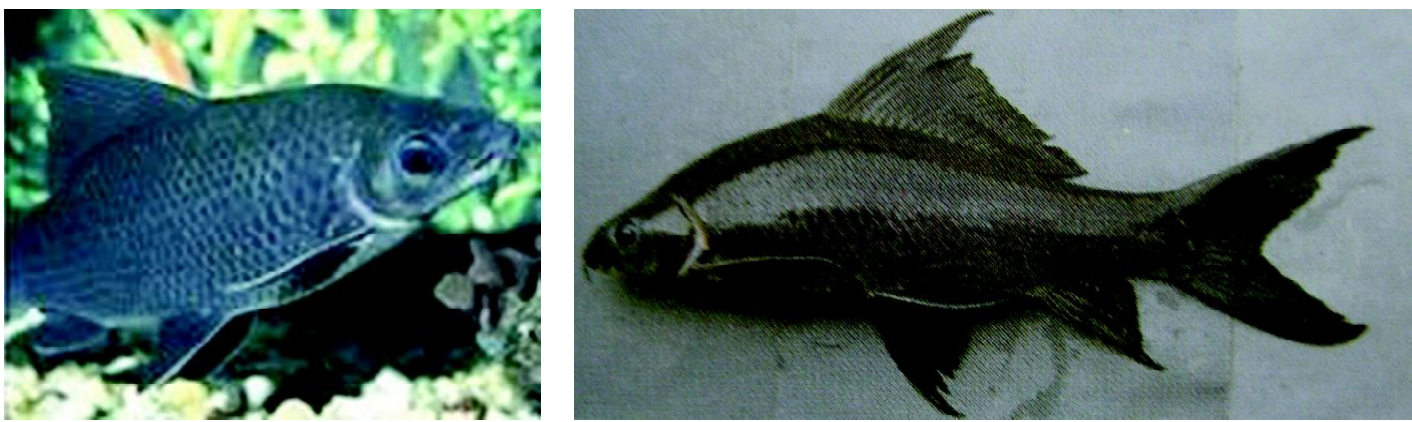

Nama Inggris/nama dagang

Nama Indonesia/nama daerah

Deskripsi morfologi

Habitat dan perkembangbiakannya
: Flying fox

: Seluang batu, susur batang merah, saleman, selimang

: Panjang maksimum mencapai $16 \mathrm{~cm}$. M empunyai dua pasang sungut; sirip punggung, sirip dubur, dan sirip perut memiliki bercak hitam; sebuah garis warna lebar memanjang. Terdapat satu garis putih terbentuk antara bercak hitam di bagian punggung dengan jalur sisi tersebut

Hidup di sungai-sungai yang agak deras dan jernih dengan suhu air $23^{\circ} \mathrm{C}-$ $26^{\circ} \mathrm{C}$, alkalinitas 4- $30 \mathrm{mg} / \mathrm{L} \mathrm{CaCO}_{3}$ dibagian demersal perairan tawar; $\mathrm{pH}$ 6,57,0; dH 5-8. Makanannya cacing udang, insekta (serangga) dan bagian tanaman

: Sumatera Selatan, Jambi, Riau, Sumatera Barat, Sumatera Utara 
Luciosoma setigerum

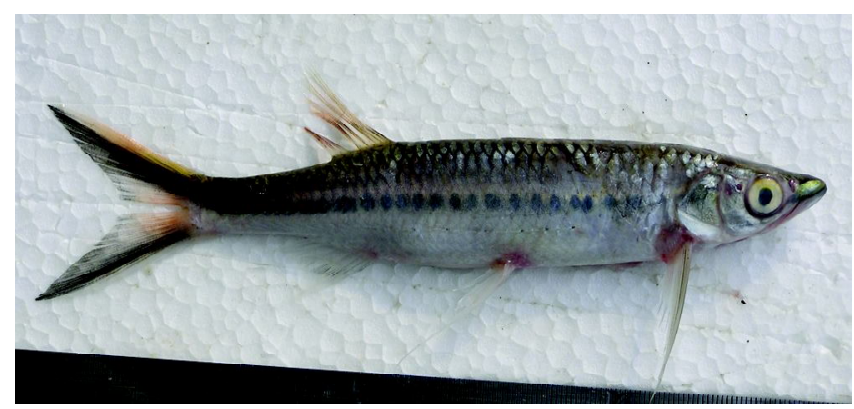

Nama Inggris/nama dagang

Nama Indonesia/nama daerah

Deskripsi morfologi

Habitat dan perkembangbiakannya
: Apollo Sharkminnow

: Juo, juar

: Panjang maksimum yg dicapai 26,5 cm. Jari-jari lunak sirip punggung 9 buah; jari-jari lunak sirip dubur 8 buah

: Hidup di sungai berarus lemah berdasar sampah dedaunan dan kayu-kayu kering di bagian dasarnya dengan alkalinitas $4-30$ mg/ $\mathrm{CaCO}_{3}$; Suhu air antara $23^{\circ} \mathrm{C}-26^{\circ} \mathrm{C}$ dan $\mathrm{pH} 6,7-7,8$. Makanannya hewan hewan kecil dan dedritus

Luciosoma trinema

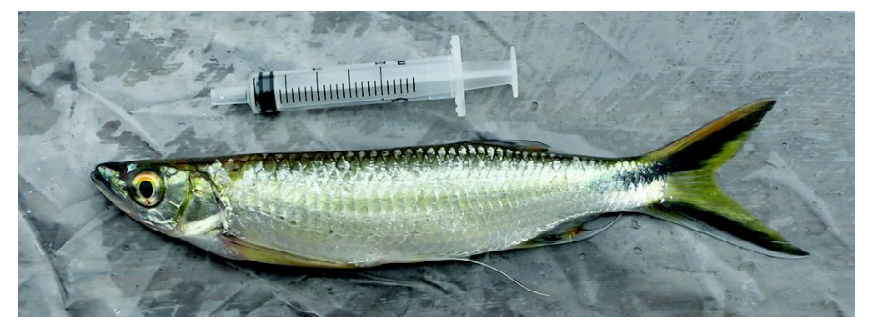

Nama Indonesia/nama daerah

Deskripsi morfologi

Habitat dan perkembangbiakannya

Penyebaran
: Ikan juo, sejuar, juajo, nyenyuar

: Panjang maksimum yang dicapai $25,5 \mathrm{~cm}$. Sungut sangat kecil atau tidak ada, ekor bagian bawah mempunyai garis warna di pinggiran dalamnya; jarijari di tengah sirip ekor tidak berwarna

: Habitat di bagian demersal perairan tawar di hulu sungai yang berarus sedang dan agak jernih bagian dasarnya di mana terdapat potongan kayu dan sampah dedaunan, alkalinitas antara $14-59 \mathrm{mg} / \mathrm{L} \mathrm{CaCO} 3^{\prime}$ suhu air antara $28,7^{\circ} \mathrm{C}-30^{\circ} \mathrm{C}$ dan pH antara 6,5-7; dH 5-8. Makanan berupa bahan nabati, serangga

: Di seluruh pulau Sumatera 
Puntioplites waandersi

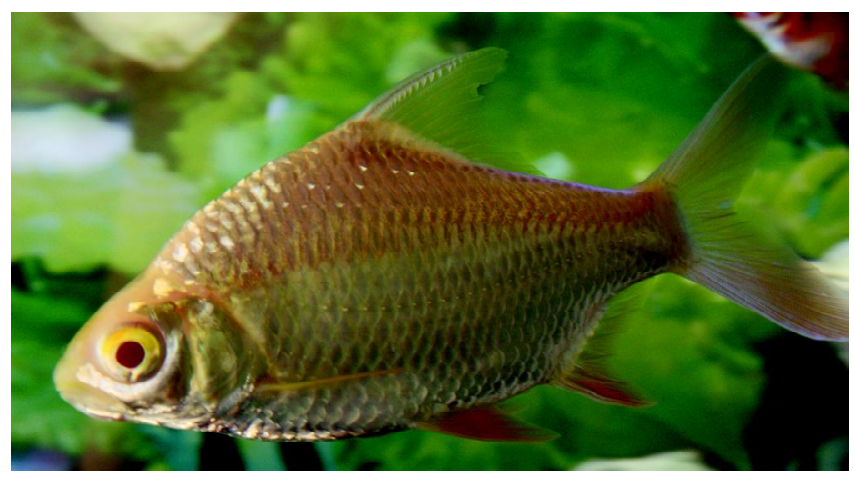

Nama Inggris/nama dagang

Nama Indonesia/nama daerah

Deskripsi Morfologi

Habitat dan perkembangbiakannya
: Barb

: Kepiat, Pahat, Umpan

: Panjang maksimum mencapai $50 \mathrm{~cm}$. Jari-jari sirip dubur yang terakhir tidak bergerigi di bagian depannya; 30-38 tapis insang (gill rakers) pada sisi terluar dari cabang pertama

Terdapat di bagian demersal perairan tawar. Dijumpai di habitat sungai besar. Bersifat herbivora, memakan tanaman air (macrophytes), tanaman tepi sungai yang masuk ke air dan alga filament juga serangga (insekta)

\section{Puntius pentazona}
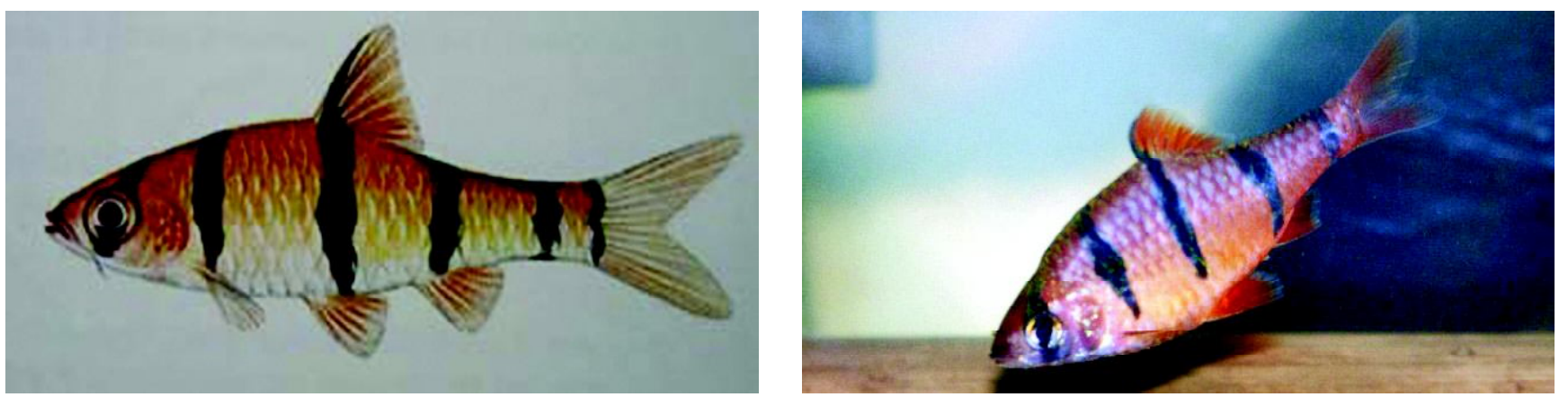

Nama Inggris/nama dagang

Nama Indonesia/nama daerah

Deskripsi morfologi

Habitat dan perkembangbiakannya

Penyebaran
: Five banded barb, Belted Barb, Belted Barb, Sixband Barb, Tiger Barb

: Baja

: Panjang maksimum mencapai $8,8 \mathrm{~cm}$

: Air tawar, benthopelagis; pH 5,0-6,0; dH 5-12

: Jambi, Riau, Sumatera Utara, Sumatera Barat 
Puntius tetrazona

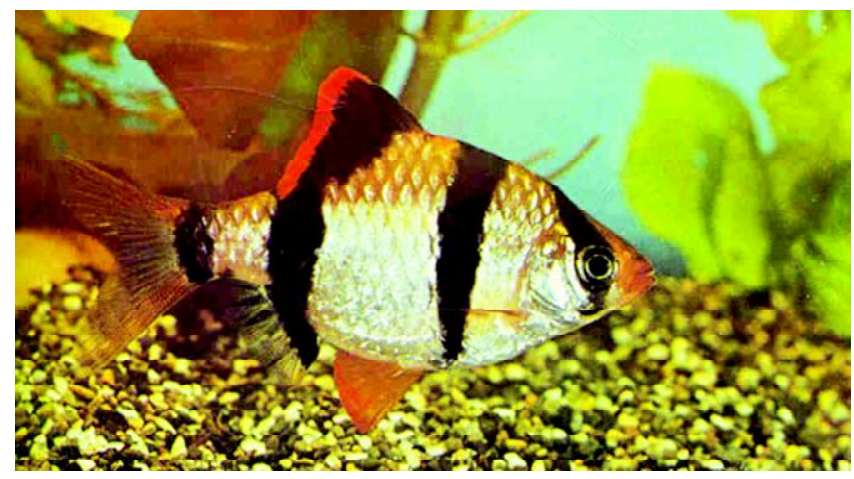

Nama Inggris/nama dagang

Nama Indonesia/nama daerah

Deskripsi morfologi

Habitat dan perkembangbiakannya

Penyebaran

\section{Rasbora argyrotaenia}
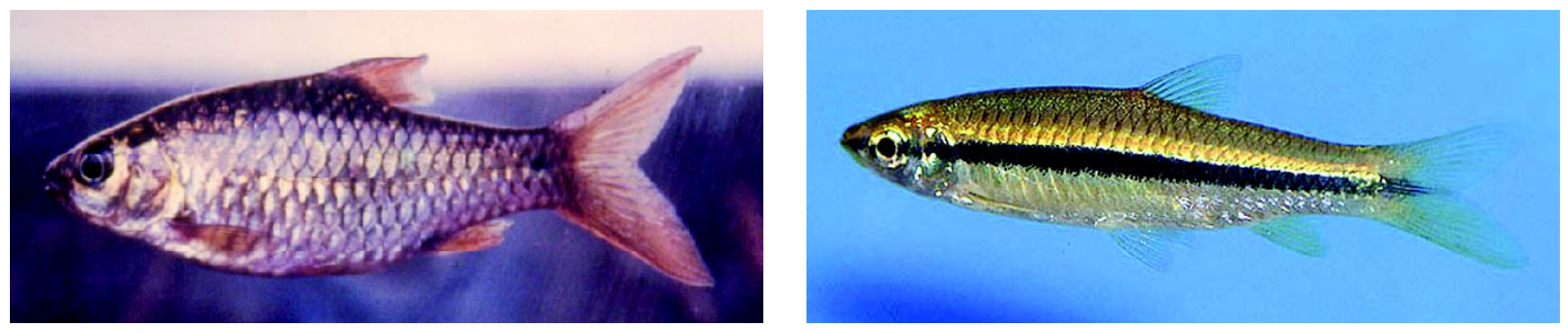

: Green Swordtail, Partbelt Barb, Sumatra Barb, Tiger Angelfish, Tiger Barb, Partbelt Barb, Tirger

: Ikan sumatera, baja

: Panjang maksimum mencapai $7 \mathrm{~cm}$

: Hidup di daerah bentopelagis perairan tawar dengan pH 6-8, dH 5-19. Temperatur $27^{\circ} \mathrm{C}$. Memakan cacing, krustase kecil dan bagian tanaman air

: Sumatera
Nama Inggris/nama dagang

Nama Indonesia/nama daerah

Deskripsi morfologi

Habitat dan perkembangbiakannya

Daerah penyebaran
: Silver rasbora

: Wader

: Panjang maksimum mencapai $12 \mathrm{~cm}$. Tak mempunyai sungut, duri sirip punggung 2 buah; jari-jari lunak sirip punggung 7 buah; duri sirip dubur 3 buah; jari-jari lunak sirip dubur 5 buah. Warna agak coklat kuning dengan latar belakang perak, bagian punggung warna gelap, tepi sisik dengan garis atau bintik berwarna coklat. Garis gurat sisi lengkap hingga bagian ekor

: Benthopelagis perairan tawar; $\mathrm{pH} 6,5-7,0 ; \mathrm{dH} 10$. Terdapat terutama di sungaisungai dan memasuk rawa banjiran. Makanan alga

: Sumatera 
Rasbora kalochroma
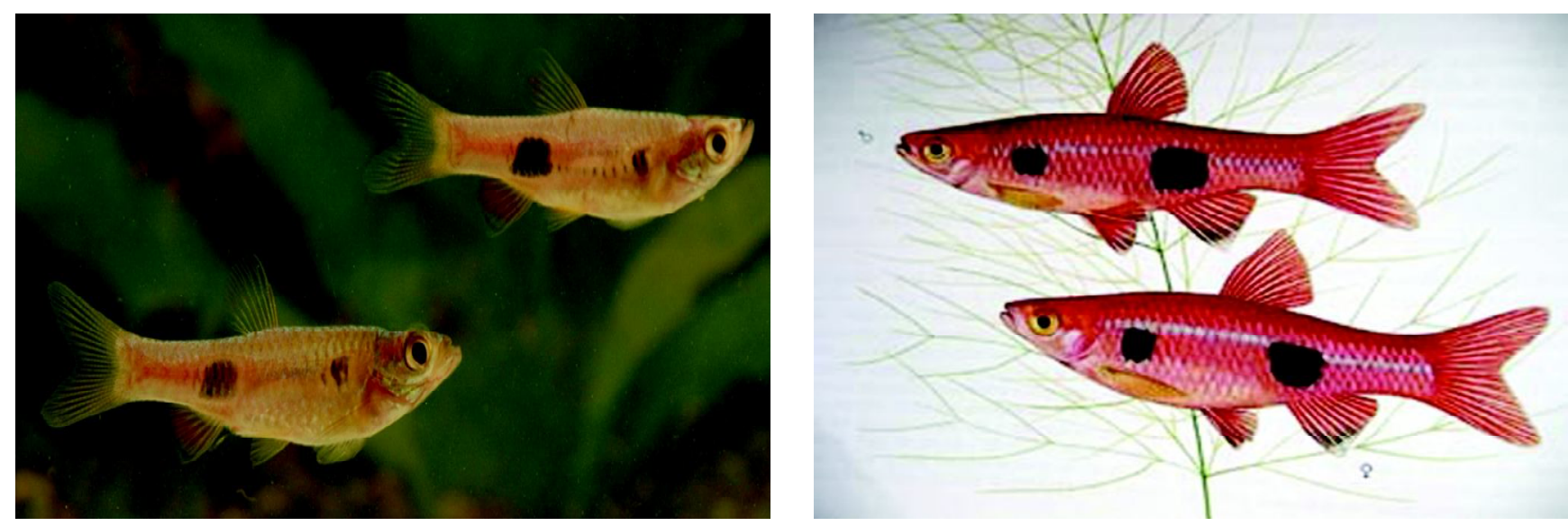

Nama Inggris/nama dagang

Nama Indonesia/nama daerah

Deskripsi morfologi

Habitat dan perkembangbiakannya
: Clown rasbora, Big-spot rasbora, Iridescent Rasbora

: Sebarau hutan

: Panjang maksimum mencapai $10 \mathrm{~cm}$. Warna ikan cantik, punggung berwarna coklat merah dengan sisi badan kemerahan dan mempunyai strip hijau pucat. Sirip-sirip berwarna merah. Sirip dubur mempunyai titik hitam

Rasbora trilineata
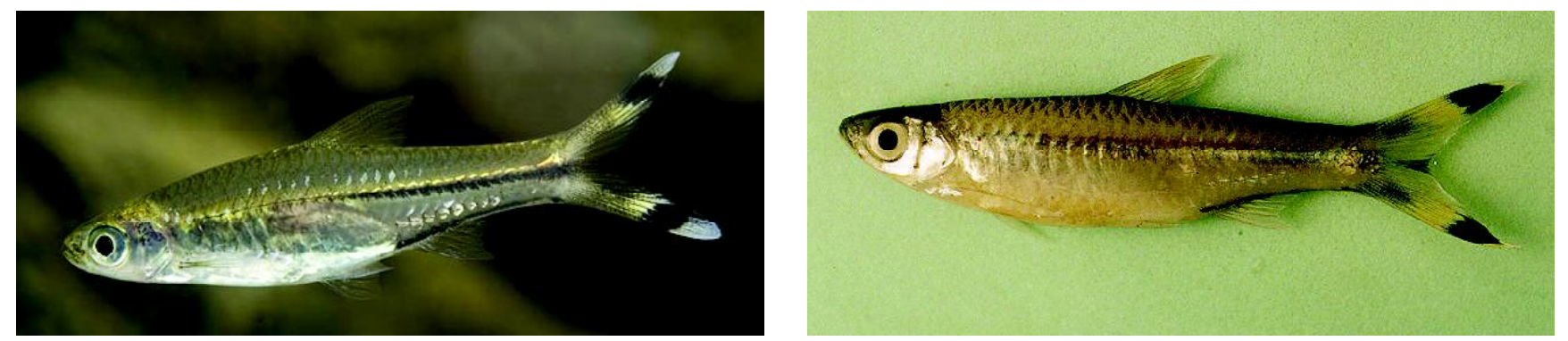

Nama Inggris/nama dagang

Nama Indonesia/nama daerah

Deskripsi morfologi

Habitat dan perkembangbiakannya
: Black Scalyfin, Black Scissortail, Scissor-Tail, Scissor-Tailed Rasbora, Scissorfish, Scissortail, Scissortail Rasbora, Three-Lined Rainbowfish, ThreeLined Rasbora, Threeline Rasbora

: Srigunting, Bada, Pantau Bana, Seluang

: Panjang maksimum mencapai $13 \mathrm{~cm}$. Jari-jari sirip lunak 9 buah; jari-jari lunak sirip dubur 8 buah. Sebuah garis pendek kehitaman pada setiap sisi sepanjang dasar sirip dubur, kedua garis ini menyatu di belakang sirip dubur dan memanjang ke dasar sirip ekor sepanjang tepi bagian bawah batang ekor

Hidup di daerah benthopelagis di danau, rawa, daerah aliran sungai yang tenang, biasanya di daerah terbuka; $\mathrm{pH} 6,0-8,0$; $\mathrm{dH} 5-12$; suhu $23^{\circ} \mathrm{C}-25^{\circ} \mathrm{C}$. Makanan utamanya serangga, juga memakan cacing dan udang 
Schismatorhynchos heterorhynchos
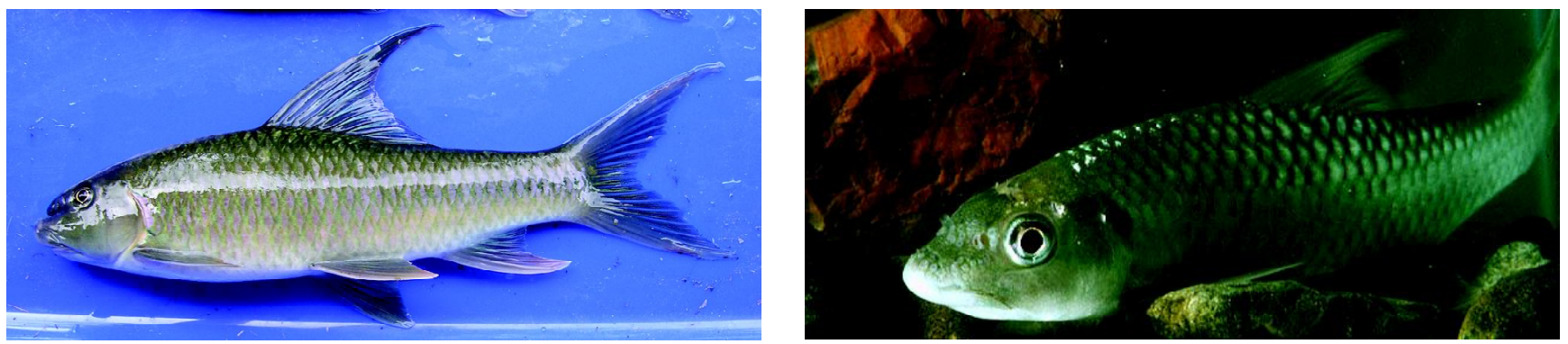

Nama Indonesia/nama daerah

Deskripsi morfologi

Habitat dan perkembangbiakannya

Daerah penyebaran

Famili : Datnioididae

Datnioides quadrifasciatus

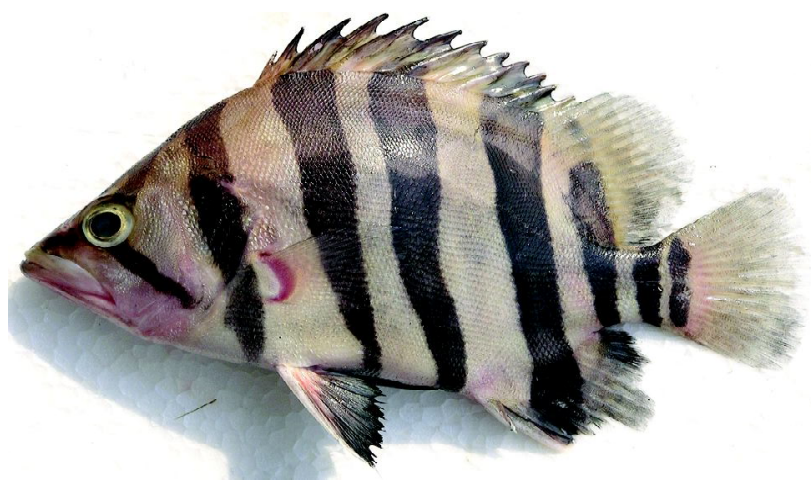

: Ikan cawing hidung, cawang hidung

: Panjang maksimum mencapai $28,3 \mathrm{~cm}$. Moncong terbelah oleh celah horizontal ke atas dan ke bawah di mana terdapat barisan tubus-tubus (tubercles) keras

: Habitatnya di hulu sungai berair deras dan jernih berpasir dengan alkalinitas 14-59 mg/L CaCO ${ }_{3}$, suhu air antara $28,7^{\circ} \mathrm{C}-32^{\circ} \mathrm{C}$ dan pH antara 6,9-7,8. Ikan ini termasuk golongan ikan omnivora tetapi umumnya memakan bahan nabati

: Sumatera (Solok, Lahat, dan Batusangkar), Kalimantan (Kapuas, Mahakam, dan Kinabatangan). Di Sumatera Selatan sekarang hanya dijumpai di daerah Musi Rawas, walaupun dahulu banyak dijumpai di hulu Sungai Musi dan anakanak sungainya. Hal ini diduga karena adanya perubahan ekologi akibat berubahnya habitat karena deforestrasi atau penggundulan hutan
Nama Inggris/nama dagang

Nama Indonesia/nama daerah

Deskripsi morfologi

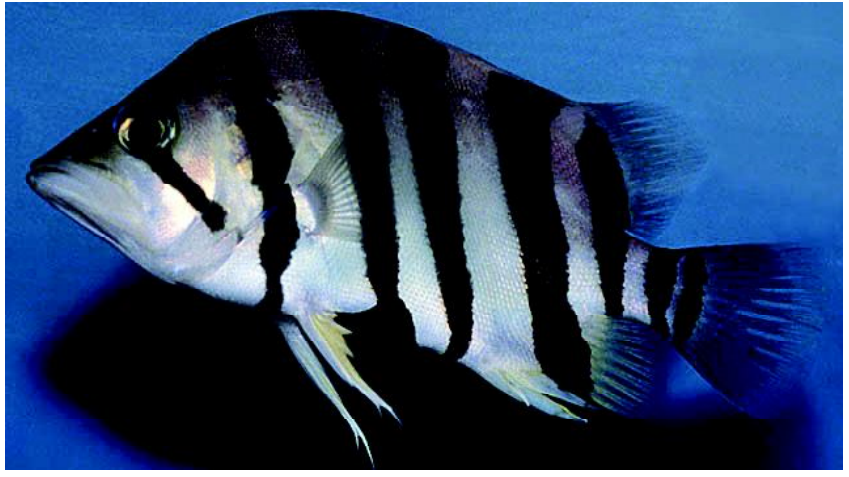

: Finescale tigerfish

: Ikan lang, ringan, ringau

: Panjang maksimum mencapai $45 \mathrm{~cm}$. Ikan ini dicirikan dengan susunan jari-jari sirip keras dan luak : D XII, 13-14 A III. Sisik pada gurat sisi 70 buah, 8-10 pita warna gelap melintang yang makin dewasa makin bersatu, sebuah bintik gelap pada tutup insang. Ikan ini bersifat predator yang hidup pada perairan dengan $\mathrm{pH}$ antara $6-7,8$, suhu air antara $26,5^{\circ} \mathrm{C}-31^{\circ} \mathrm{C}$ dan alkalinitas antara $7-100 \mathrm{mg} / \mathrm{L} \mathrm{CaCO}_{3}$ 
Famili : Hemiramphidae- Halfbeaks

Dermogenys pusilla

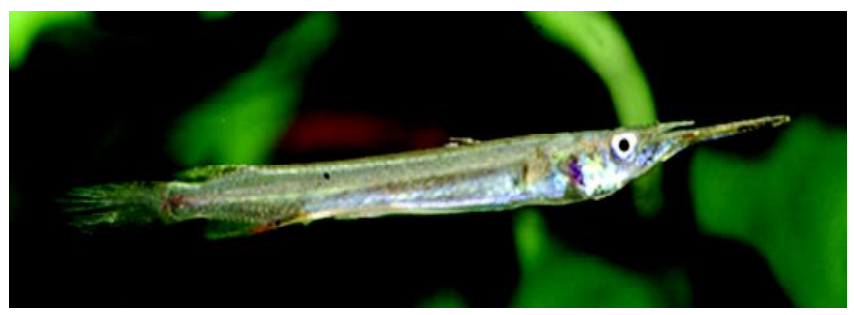

Nama Inggris/nama dagang

Nama Indonesia/nama daerah

Deskripsi Morfologi

Habitat dan perkembangbiakannya
: Wrestling halfbeak, Freshwater Halfbeak, Freshwater Halfbeak, Half Beak, Halfbeak, Needle Gar, Needle Gar, Wrestling Halfbeak, Wrestling Halfbeak

: Julung-julung, Jolong, Kacangan, Kajangan, Plentet, Sundoprono

: Panjang maksimum mencapai $7 \mathrm{~cm}$

: Hidup di bagian pelagis perairan tawar, payau, dan laut dengan kisaran $\mathrm{pH}$ $7,0-8,0 ; \mathrm{dH} 9-19$

Famili : Mastacembelidae- Spiny- Eels

Macrognathus aculeatus

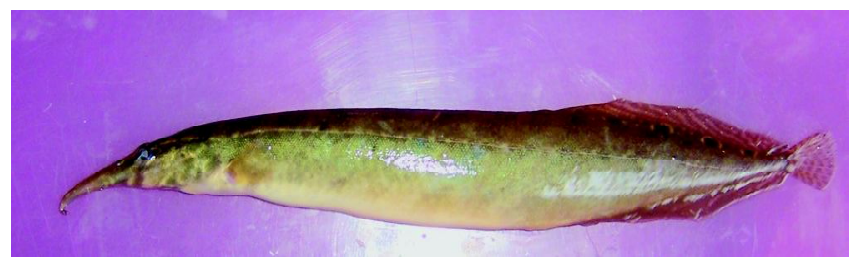

Nama Inggris/nama dagang Nama Indonesia/nama daerah Deskripsi

Habitat dan perkembangbiakannya

Penyebaran
: Lesser Spiny Eel, Elephant Trunk Fish, Spiny Eel

: Ikan tilan buluh, Gerit, Silih, Silih Cina

: Panjang maksimum mencapai $38 \mathrm{~cm}$. Duri sirip punggung14-20 buah; jarijari lunak sirip punggung 52-56 buah; duri sirip dubur 3 buah; jari-jari lunak sirip dubur 50-54 buah. Sirip punggung dan dubur ditumbuhi sebaris duriduri tajam yang diikuti satu bagian lunak yang bersatu, kedua sirip berdiri sendiri tak bersatu dengan sirip ekor. Tidak mempunyai sirip dada

: Hidup di bagian benthopelagis; potamodromous; perairan tawar; payau; $\mathrm{pH}$ $6,5-7,5 ; \mathrm{dH}$ 15. Hidup di sungai-sungai besar. Juga dijumpai di dataran rendah yang basah dan bergambut

: Jambi, Sumatera Selatan, Riau, dan Sumatera Utara 
Mastacembelus erythrotaenia

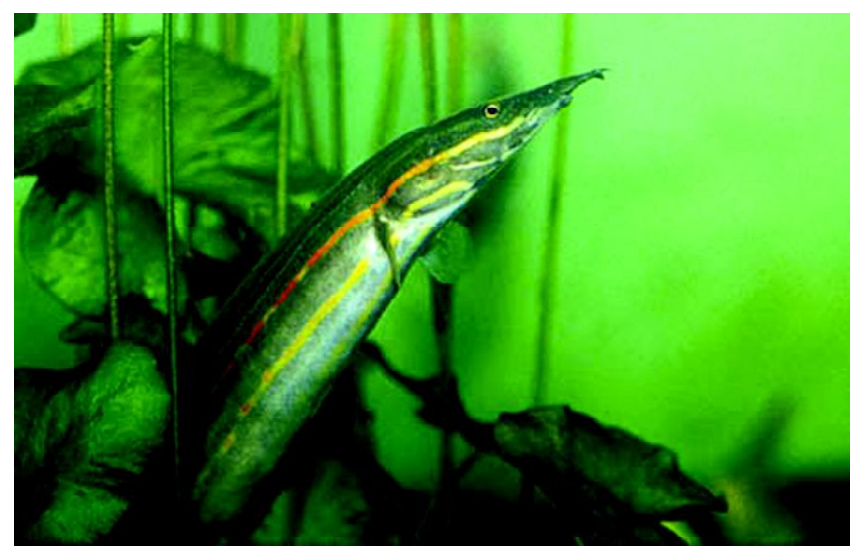

Nama Inggris/nama dagang

Nama Indonesia/nama daerah

Deskripsi morfologi

Habitat dan perkembangbiakannya
: Fire Eel, flaming Eel, Spotted Fire Eel

: Ikan tilan merah

: Panjang maksimum mencapai $100 \mathrm{~cm}$. Badannya sangat panjang dengan ekor pipih datar dan barisan duri kecil sepanjang punggung di depan jari-jari sirip punggung. Tidak memiliki sirip perut. Moncongnya memanjang membentuk hidung mancung dan lubang hidungnya terletak di samping lubang hidung memiliki 2 tonjolan halus kecil seperti jari; 33-40 buah duri sirip punggung; 68- 85 buah jari-jari pada sirip punggung dan sirip dubur. Terdapat pita warna merah di kepala (berwarna kuning atau putih kalau mati), jari-jari sirip ekor 14- 15 buah, bersambung dengan sirip punggung dan sirip dubur

: Perairan yang tenang (demersal) air tawar dengan vegetasi yang lebat atau pada lumpur yang lunak di mana mereka menunggu mangsanya. Suhu air $24^{\circ} \mathrm{C}-32^{\circ} \mathrm{C}$, pH 6-8, dan dH 5-19. Makanannya berupa ikan atau serangga, cacing, kepiring rawa, dan bagian tanaman

Famili : Notopteridae- Knifefishes

Chitala lopis
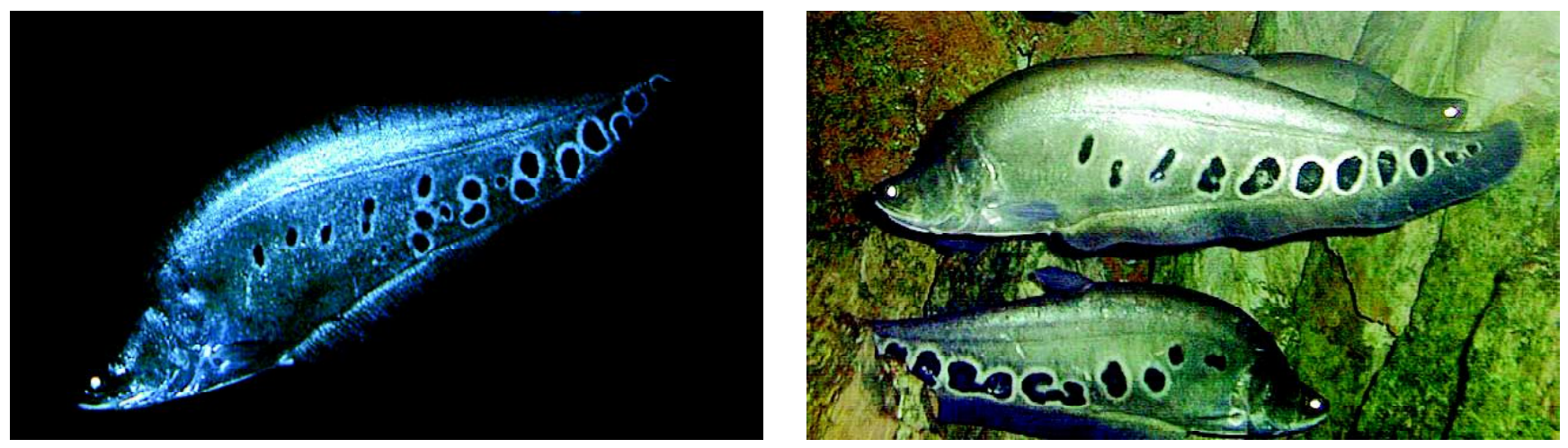

Nama Inggris/nama dagang

: Clown Knifefish, Clown Knifefish, Feather Back, Feather Back, Featherback, Featherback, Knife Fish, Knife Fish, Thousand Dollar Knife Fish, Thousand Dollar Knife Fish 

Nama Indonesia/nama daerah $\quad$ : Ikan belida, lopis
Deskripsi morfologi
: Panjang maksimum mencapai $122 \mathrm{~cm}$. Jari-jari lunak sirip punggung 9 buah jari-jari lunak sirip dubur 117-127 buah. Anak ikan ini mempunyai 13 hingga 15 pita lebar menyilang miring yang berwarna gelap pada sisi tubuhnya. Sirip perut bersatu pada dasar sirip. Sirip dubur bersambungan dengan sirip ekor

Habitat dan perkembangbiakannya $\quad$ : Perairan demersal air tawar, $\mathrm{pH}$ 6-8; $\mathrm{dH}$ 5-19. Hidup di sungai-sungai perairan tawar, danau, cekungan, rawa dalam, waduk. Makanannya serangga air, siput, udang, dan ikan kecil. M eletakkan telur di batang-batang kayu tenggelam

\section{Notopterus notopterus}
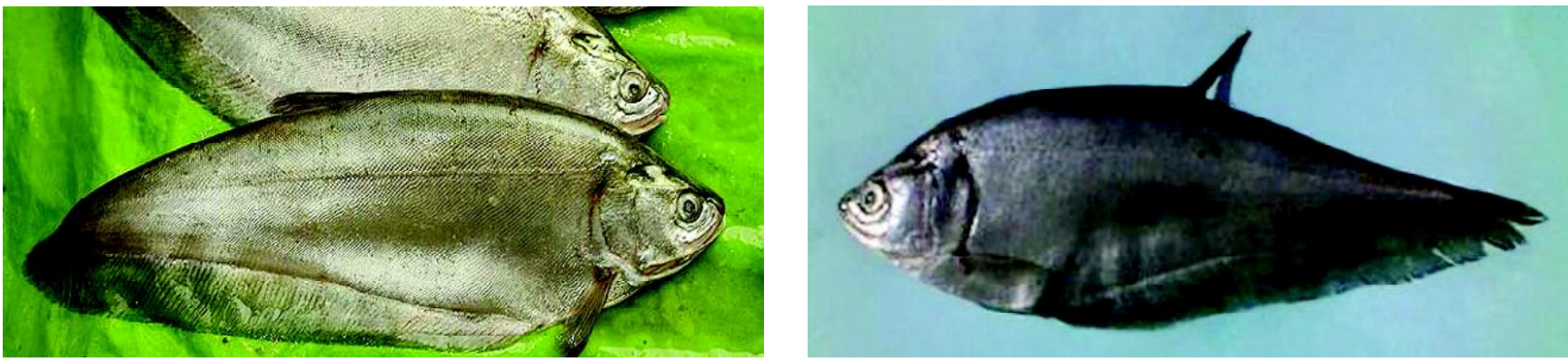

Nama Inggris/nama dagang

Nama Indonesia/nama daerah

Deskripsi morfologi

Habitat dan perkembangbiakannya
: Bronze featherback, Asiatic Knifefish, Common Knife Fish, Feather Back, Grey Featherback

: Ikan putak

: Panjang maksimum mencapai $30 \mathrm{~cm}$. Jari-jari lunak sirip punggung 7-9 buah; Jari-jari lunak sirip dubur 97-111 buah. Ikan dewasa berwarna coklat merata dan bentuk punggung kepala yang cembung atau agak cekung; yuwana $(<5$ cm SL) mempunyai pita warna gelap seluruh badannya; sisik di depan operculum ada 6- 8 baris; badan kepala berwarna putih-perak dengan banyak titiktitik abu-abu kecil

Demersal; potamodromous; air tawar; payau; pH 6,0-6,5; dH 3-8. Dijumpai di sungai kecil yang jernih dan memasuki perairan payau, danau yang tenang dan beraliran lemah, di rawa banjiran, kanal-kanal. Memakan serangga, ikan, udang, dan akar muda dari tanaman air. Aktif pada temaram dan malam hari. Bergerombol dan memijah setiap tahun selama musim hujan 
Famili : Osphronemidae- Giant Gouramies

Sphaerichthys osphromenoides
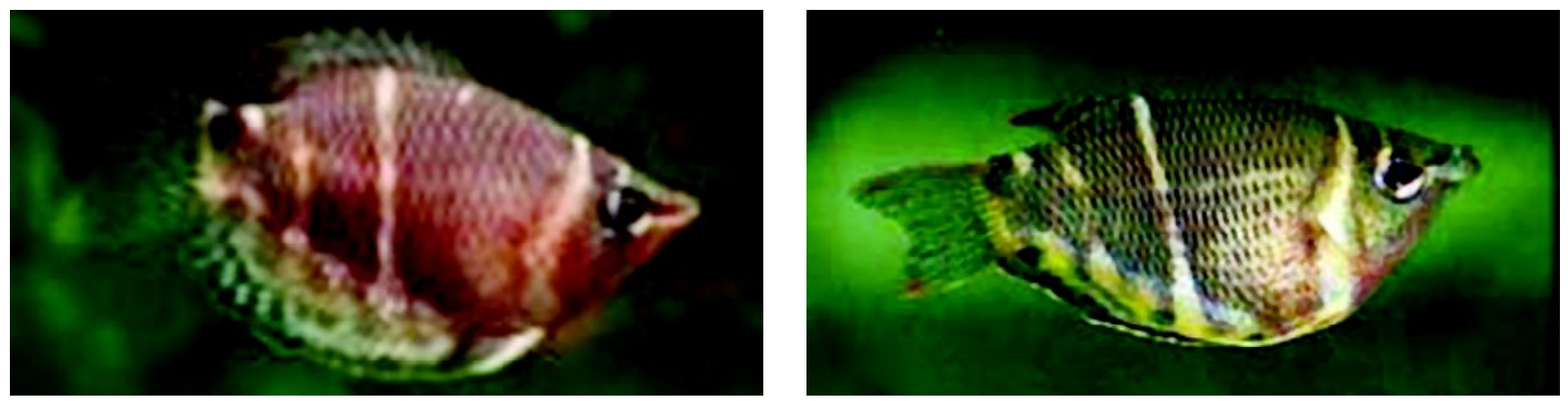

Nama Inggris/nama dagang

Nama Indonesia/nama daerah

Deskripsi morfologi

Habitat dan perkembangbiakannya

Penyebaran

\section{Betta brownorum}
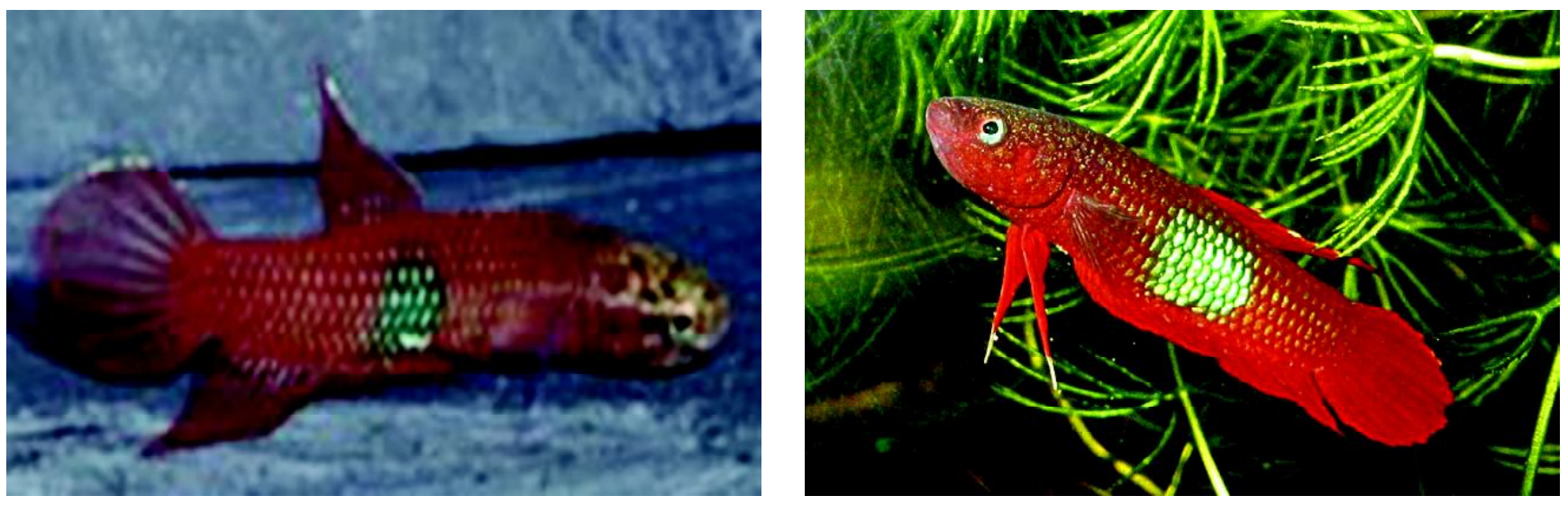

Nama Indonesia/nama daerah

Deskripsi morfologi

Habitat
: Gouramies, Chocolate Gourami

: Sepat batik, coklat gurame

: Panjang maksimum mencapai $6 \mathrm{~cm}$. Moncong pendek; awal sirip punggung hampir tepat di atas lawal sirip dubur. Badan mempunyai empat jalur melintang berwarna putih

: Berbagai daerah rawa banjiran di tepi hutan, di daerah gambut, benthopelagic; air tawar; pH 4,0-6,0; dH 0-4. Mengerami telur di mulut, pemakan segala (omnivora). Sarang dibangun dari busa di mana mereka menyimpan telurnya di dalam untuk memijah. Memijah pada ukuran 3,5 cm. Ciri kelamin sekunder: ikan jantan mempunyai titik kuning di depan sirip punggung

: Dijumpai di Provinsi Jambi, Riau, Sumatera Utara 
Betta burdigala
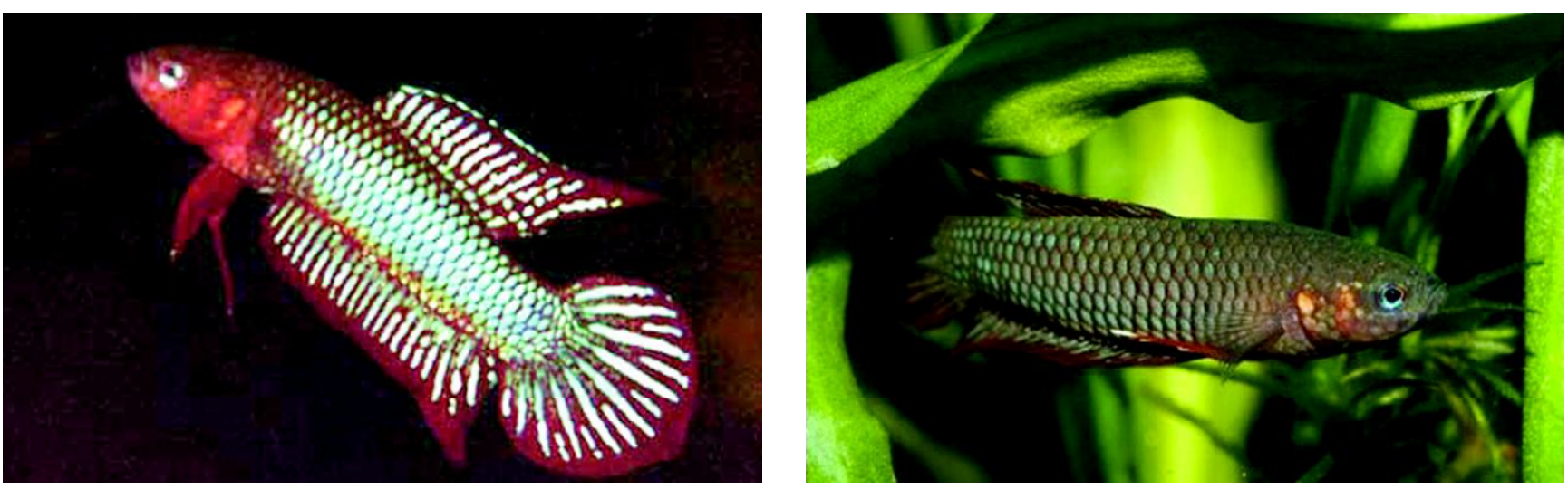

Nama Inggris/nama dagang

Nama Indonesia/nama daerah

Deskripsi morfologi

Habitat dan perkembangbiakannya

Daerah penyebaran

Trichogaster leerii
: Skunk Corydoras

: Ikan cupang

: Panjang maksimum mencapai $6 \mathrm{~cm}$. Duri sirip punggung 1 buah; jari-jari lunak sirip punggung 13-14 buah; Duri sirip dubur 1-2 buah; jari-jari lunak sirip dubur 23-24 buah

: Hidup di bagian bentopelagis perairan tawar, di hutan gambut. Pemeliharaan secara komunal tidak akan jadi agresif jika ruang geraknya cukup. Memijah pada ukuran $10 \mathrm{~cm}$. Suhu air untuk pemeliharaan temperatur $22^{\circ} \mathrm{C}-26^{\circ} \mathrm{C} ; \mathrm{pH}$ $4,0-6,0$

: Merupakan ikan asli dari Bangka
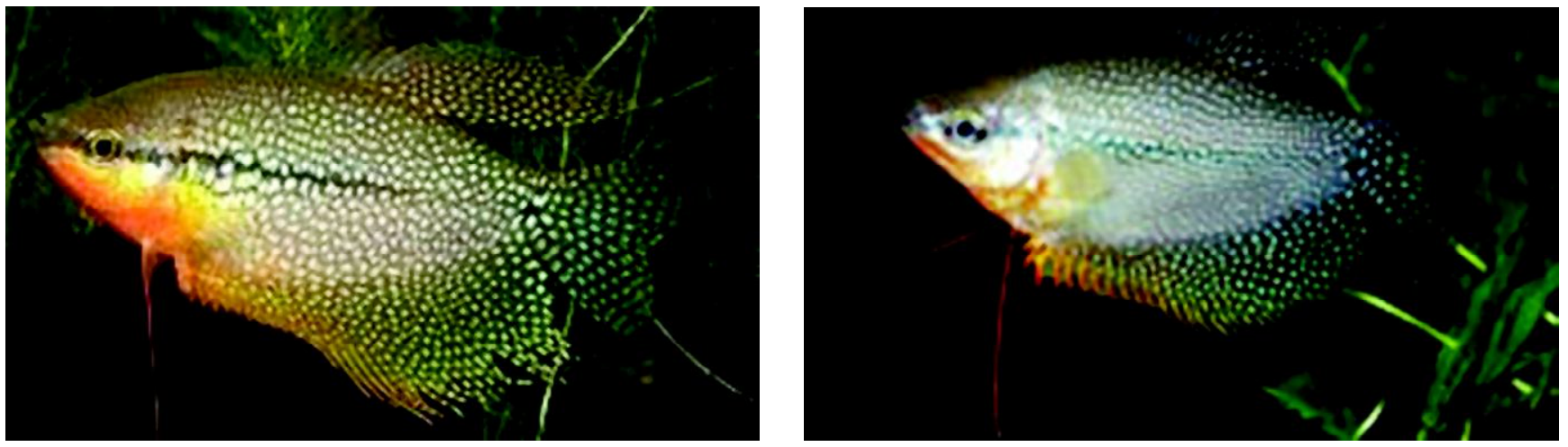

Nama Inggris/nama dagang

Nama Indonesia/nama daerah

Deskripsi
: Pearl gouramy, Diamond Gourami, Lace Gourami, M osaic Gourami

: Sepat mutiara

: Panjang maksimum mencapai $12 \mathrm{~cm}$. Jari-jari lunak sirip punggung berjumlah 10; di dalam Osphroneminae duri sirip punggung 11-13; jari-jari lunak 1113, duri sirip dubur 9-12; jari-jari lunak 16-22, semua sisik ctenoid. Beberapa spesies mengerami telur di dalam mulut dan yang lainnya membuat sarang dari buih 
Habitat dan perkembangbiakannya $\quad$ : Memijah pada ukuran $10 \mathrm{~cm}$. Hidup di air yang tenang dan kadang-kadang hidup di perairan dengan konsentrasi oksigen rendah di antara vegetasi yang lebat, berkembang biak pada perairan yang terbatas dan genangan air yang tenang atau perairan yang sempit dan rawa-rawa. Ikan jantan membangun sarang berbusa di mana mereka menyimpan telurnya untuk memijah. Suhu air untuk pemijahan $27^{\circ} \mathrm{C}-28^{\circ} \mathrm{C}$ dengan $\mathrm{pH} 7$

Penyebaran

: Sumatera

\section{Trichogaster trichopterus}
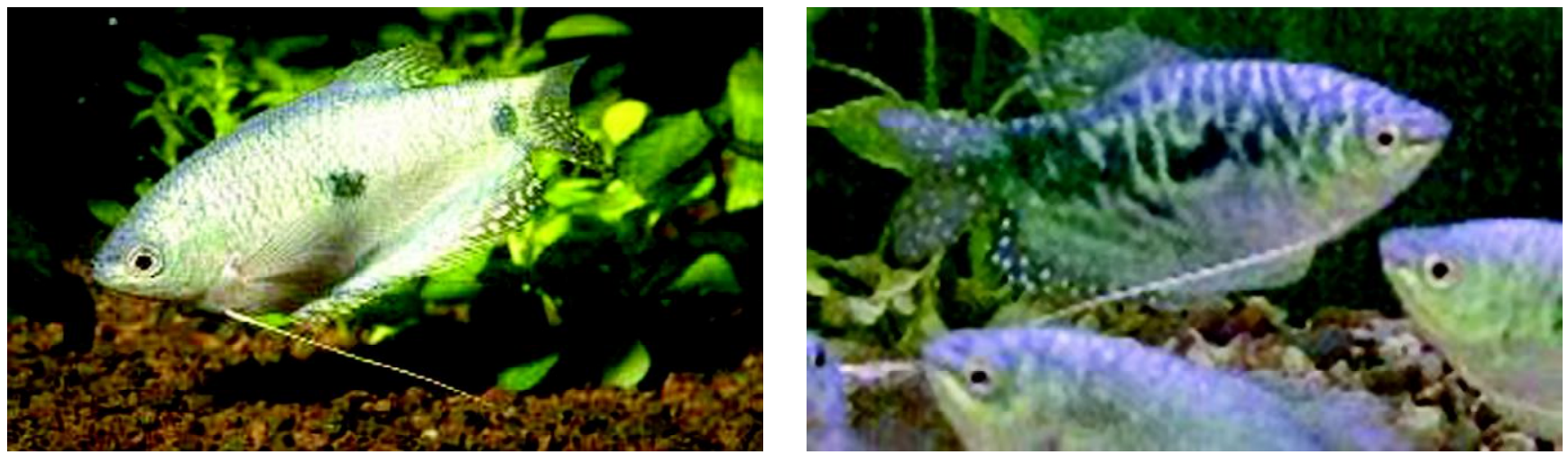

Nama Inggris/nama dagang

Nama Indonesia/nama daerah

Deskripsi morfologi

Habitat dan perkembangbiakannya
: Blue Gourami, Cosby Gourami, Giant Gouramy, Gold Gourami, Golden Gourami, Opaline Gourami, Three Spot Gourami, Three-Spot Gourami, Three-Spot Gouramy, Threespot Gourami, Two-Spot Gouramy

: Sepat rawa

: Panjang maksimum mencapai $15 \mathrm{~cm}$. Duri sirip punggung 6-8 buah; jari-jari lunak sirip punggung 7-10 buah; duri sirip dubur 9-12 buah; jari-jari lunak sirip dubur 30-38 buah. Warna badan kehijauan sampai kebiruan dengan beberapa pita miring berwarna gelap dan sebuah bercak di tengah sisi pada pangkal sirip ekor

: Kebanyakan hidup di air yang tenang dan kadang-kadang hidup di perairan dengan konsentrasi oksigen rendah di antara vegetasi yang lebat. Yaitu daerah lakustrin dengan pH 6-8 dan kesadahan normal, dH 5-19. Ikan ini akan memijah setelah induk jantan membangun sarang gelembung busa di antara tanaman air yang mengapung, induk siap pijah pada ukuran $7,5 \mathrm{~cm}$. Mampu hidup pada kisaran suhu yang relatif tinggi, antara $21^{\circ} \mathrm{C}-31^{\circ} \mathrm{C}$, untuk pemijahan terkontrol suhu berkisar antara $25^{\circ}-30^{\circ} \mathrm{C}$. M akanannya alga

Penyebaran
: Seluruh Sumatera 
Famili : Osteoglossidae

Scleropages aureus, Pouyaud, Sudarto, \& Teugels, 2003

Nama Inggris/nama dagang

Nama Indonesia/nama daerah

Deskripsi morfologi

Habitat dan perkembangbiakannya

Penyebaran

Scleropages formosus, Pouyaud, Sudarto, \& Teugels, 2003

: Jambi dan Riau
: Asian Bony tongue, dragon fish, arowana

: Tangkeleso, tangkelese, arwana.

: Badan sangat mampat dan abdomennya berlunas, mempunyai bukaan mulut yang sangat luas, dan rahang yang sangat menonjol. Dua sungut berdaging didapati pada dagu, sisiknya berwarna hijau buah zaitun dengan bagian tepinya berwarna keemasan. Perutnya berwarna putih kehijauan. Jari-jari sirip punggung, sirip dubur dan sirip ekor juga berwarna hijau tua dengan membran yang berwarna putih kehijauan. Sirip dada berwarna hijau tua di bagian punggung dan putih di bagian perut. Sirip perut berwarna keputih-putihan

: Hidup di sungai dan danau dengan vegetasi. Melakukan pemijahan pada musim penghujan. Ikan jantan mengerami telur selama 1-2 bulan
Nama Inggris/nama dagang

Nama Indonesia/nama daerah

Deskripsi morfologi

Habitat dan perkembangbiakannya

Penyebaran

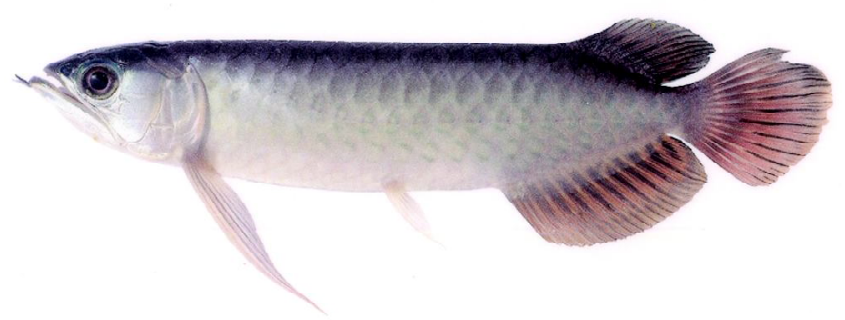

: Asian bony tongue, arowana

: Arwana, tangkeleso, tangkelese

: Scleropages formosus adalah salah satu ikan-ikan Indonesia yang dikategorikan sebagai jenis yang terancam punah oleh International Union for the Conservation of Nature and Natural Resources (IUCN). Bentuk badan agak memanjang, sisik pada badan besar dan keras sedangkan kepalanya tidak bersisik. Badan sangat mampat dan abdomennya berlunas, mempunyai bukaan mulut yang sangat luas, dan rahang yang sangat menonjol. Dua sungut berdaging pada dagu, sisiknya berwarna hijau.

: Ikan ini bersifat predator yang hidup pada pH berkisar antara 6-7,5; dengan suhu air antara $26^{\circ} \mathrm{C}-31^{\circ} \mathrm{C}$ dan alkalinitas antara 7-100 mg/L CaCO . Ikan ini mengerami telur di mulut. Ikan ini memangsa serangga, anak katak, dan ikan kecil

: Sumatera Selatan, Jambi, dan Riau 
Scleropages macrocephalus, Pouyaud, Sudarto, \& Teugels, 2003

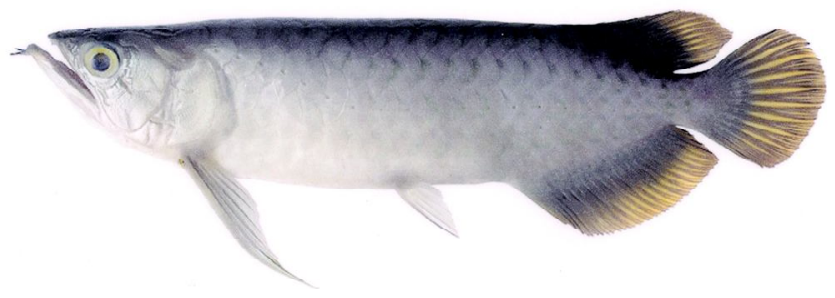

Nama Inggris/nama dagang

Nama Indonesia/nama daerah

Deskripsi morfologi

Habitat dan perkembangbiakannya

Penyebaran

Famili : Poeciliidae-poeciliids

Xiphophorus hellerii
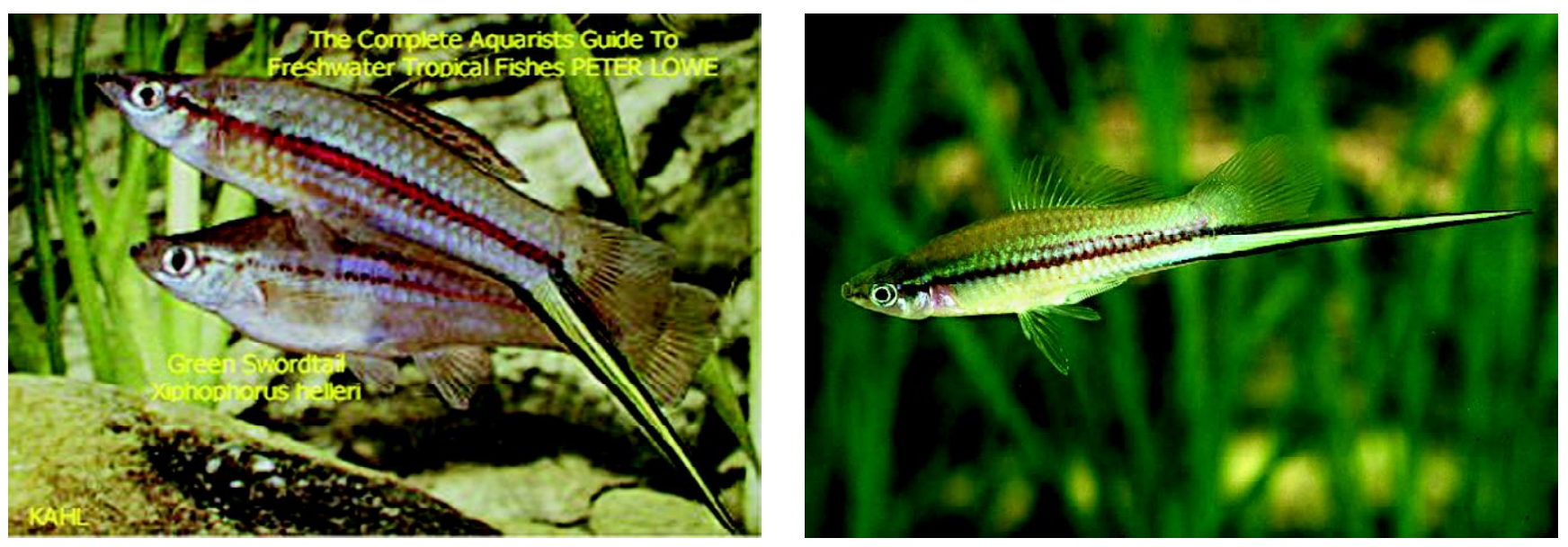

Nama Inggris/nama dagang

Nama Indonesia/nama daerah

Deskripsi morfologi
: Asian bony tongue

: Ikan arwana

: Bentuk badan agak memanjang, sisik pada badan besar, dan keras sedangkan kepalanya tidak bersisik. Bersirip punggung hampir mendekati sirip ekor, sirip dada panjang dan meruncing, bersisik besar, mempunyai dua sungut lunak pada ujung rahang bawahnya. Bersifat predator bagi ikan-ikan kecil, katak, dan binatang lainnya. Sirip dada berwarna hijau tua di bagian punggung dan putih di bagian perut. Sirip perut berwarna keputih-putihan

: Ikan ini bersifat predator yang hidup pada pH berkisar antara 6-7,5; dengan suhu air antara $26^{\circ} \mathrm{C}-31^{\circ} \mathrm{C}$ dan alkal initas antara 7-100 mg/ CaCO . Ikan ini mengerami telur di mulut dan memelihara anaknya di dalam mulut sampai anak-anak mencapai ukuran panjang kira-kira $6 \mathrm{~cm}$

: Sumatera Selatan, Jambi, dan Riau 
Habitat dan perkembangbiakannya

Daerah penyebaran

Famili : Siluridae (Sheatfishes)

Kryptopterus bicirrhis

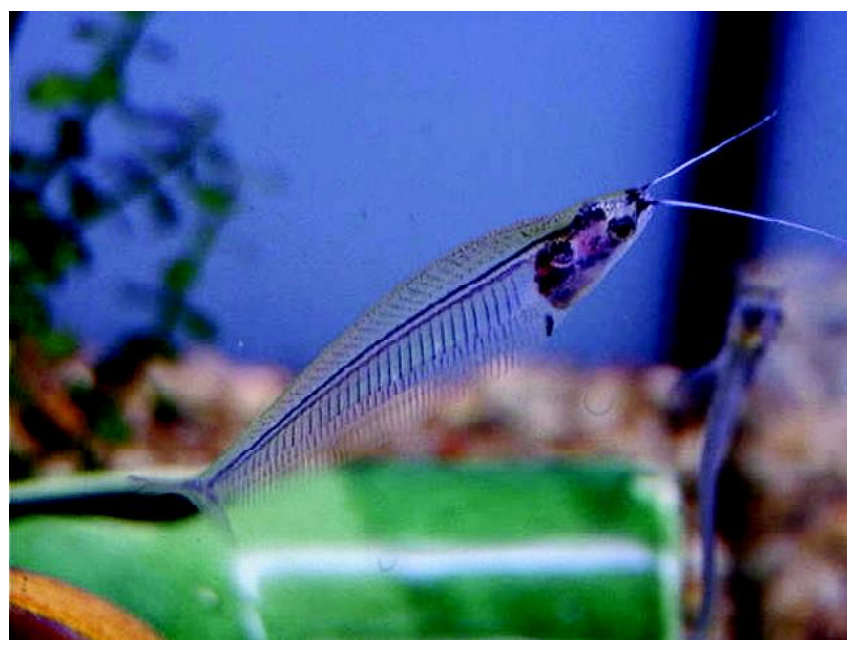

Nama Inggris/nama dagang

Nama Indonesia/nama daerah

Deskripsi morfologi

Habitat dan perkembangbiakannya ekor. Ekor pedang yang dimiliki ikan jantan merupakan kepanjangan dari sirip ekornya berwarna kuning cerah dan tepi bawah berwarna hitam lebih lebar dari bagian atasnya.

Hidup di bentopelagis perairan tawar dengan $\mathrm{pH}$ 7,0-7,5; hardness 8-12, dH 9-19; temperatur $24^{\circ} \mathrm{C}-27^{\circ} \mathrm{C}$. Ikan ini mengandung anak-anaknya. Dijumpai pada bagian sungai yang mengalir cepat, menyukai habitat yang bervegetasi lebat. Makanannya cacing, krustase, insekta, dan bagian tanaman

\section{: Sumatera Barat}


Famili : Tetraodontidae-puffers

Tetraodon palembangensis
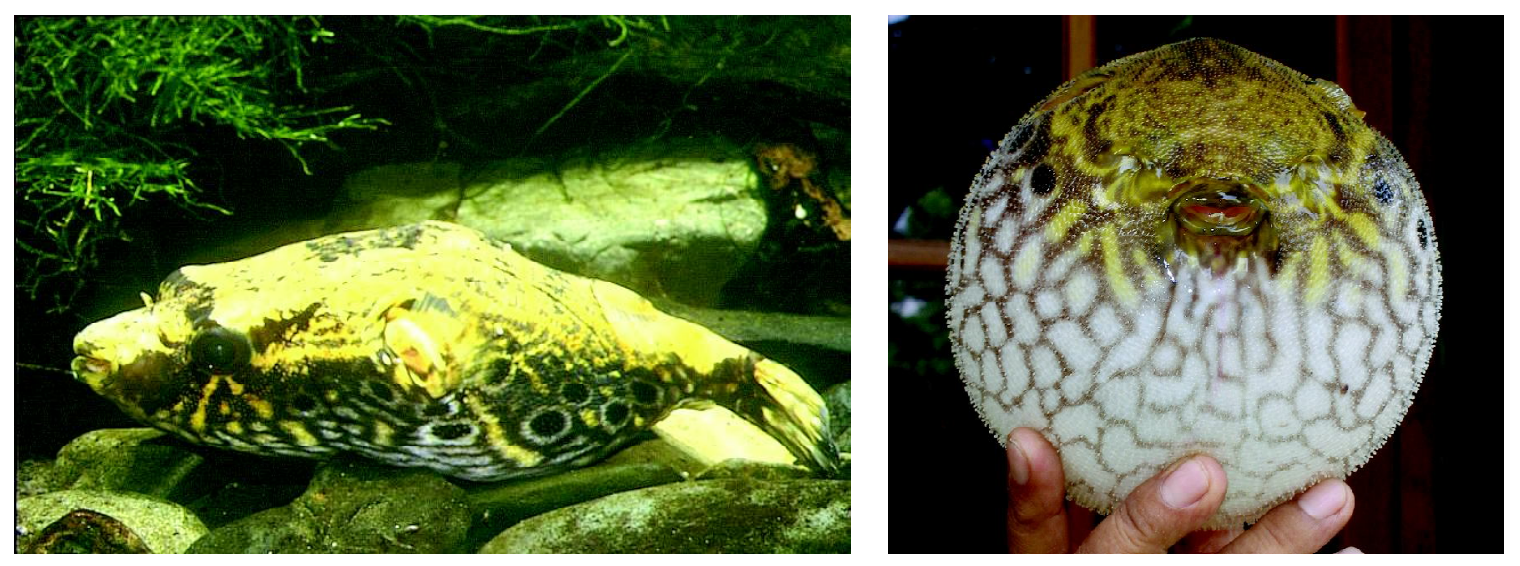

Nama Inggris/nama dagang

Nama Indonesia/nama daerah

Deskripsi Morfologi

Habitat dan perkembangbiakannya

Penyebaran
: Pufferfish

: Ikan buntal

: Panjang maksimum mencapai 19,4 cm

: Demersal; perairan tawar, sudah berhasil dibudidayakan di luar habitatnya

: Sumatera Selatan, Jambi

Famili : Toxotidae-Archerfishes

Toxotes jaculatrix
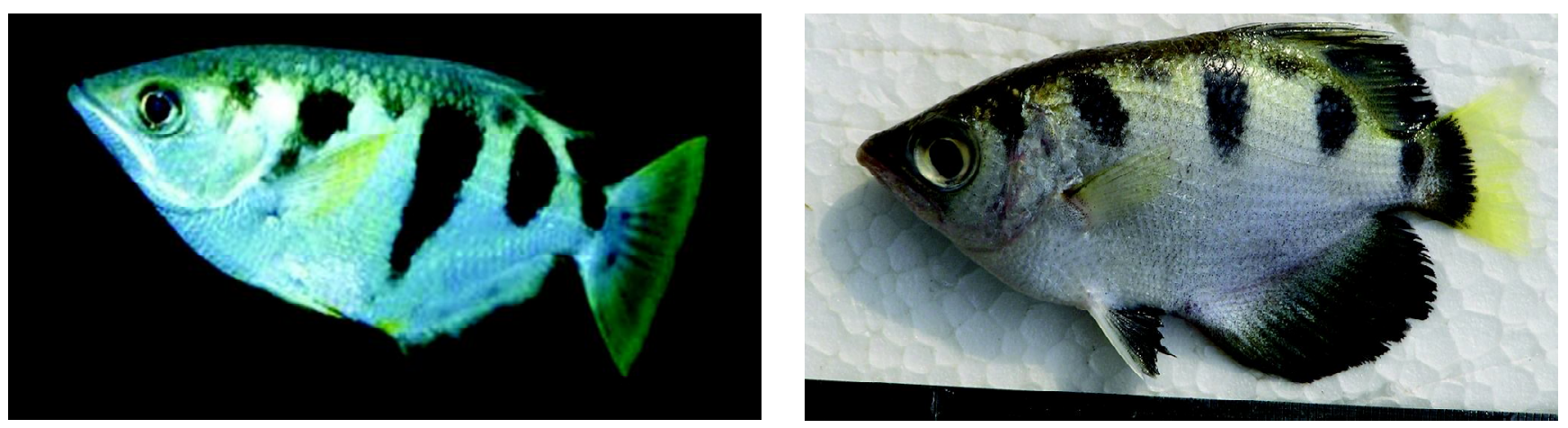

Nama Inggris/nama dagang

Nama Indonesia/nama daerah

Deskripsi morfologi
: Archerfish, Banded Archerfish, Riflefish

: Ikan sumpit

: Panjang maksimum mencapai $30 \mathrm{~cm}$. Dikenal dengan nama ikan sumpit karena kemampuannnya untuk meludah atau memancarkan air ke arah serangga atau binatang kecil lainnya di atas permukaan air sehingga mereka jatuh untuk kemudian dimakan. Duri sirip punggung 4 buah; jari-jari lunak sirip punggung 11-13 buah; duri sirip dubur 3 buah; jari-jari lunak sirip dubur 15- 17 buah. Sisik gurat sisi 26-30 buah; 4- 5 pita warna hitam pada bagian atas badan, 3-4 baris sisik di atas gurat sisi dan 3-4 baris di bawahnya. Jari- 
Media Akuakultur Volume 5 Nomor 1 Tahun 2010

jari tapis insang dari bagian bawah lengkung insang pertama 5-7 buah. Biasanya berwarna keperakan dengan 4-5 baris hitam

Habitat dan perkembangbiakannya : Hidup di rawa-rawa hutan bakau, daerah estuarin, kadang-kadang di air payau. Hidup di badan air dengan alkalinitas 1-5 mg/L $\mathrm{CaCO}_{3}$; $\mathrm{pH}$ 6,0-7,3; suhu air $25^{\circ} \mathrm{C}-30^{\circ} \mathrm{C} ; \mathrm{dH}<15$. Pada siang hari mencari makan di permukaan dan memakan benda-benda mengambang yaitu serangga air dan bagian tanaman. Kemampuan "menembak" dengan semprotan bisa mencapai jarak $150 \mathrm{~cm}$ 